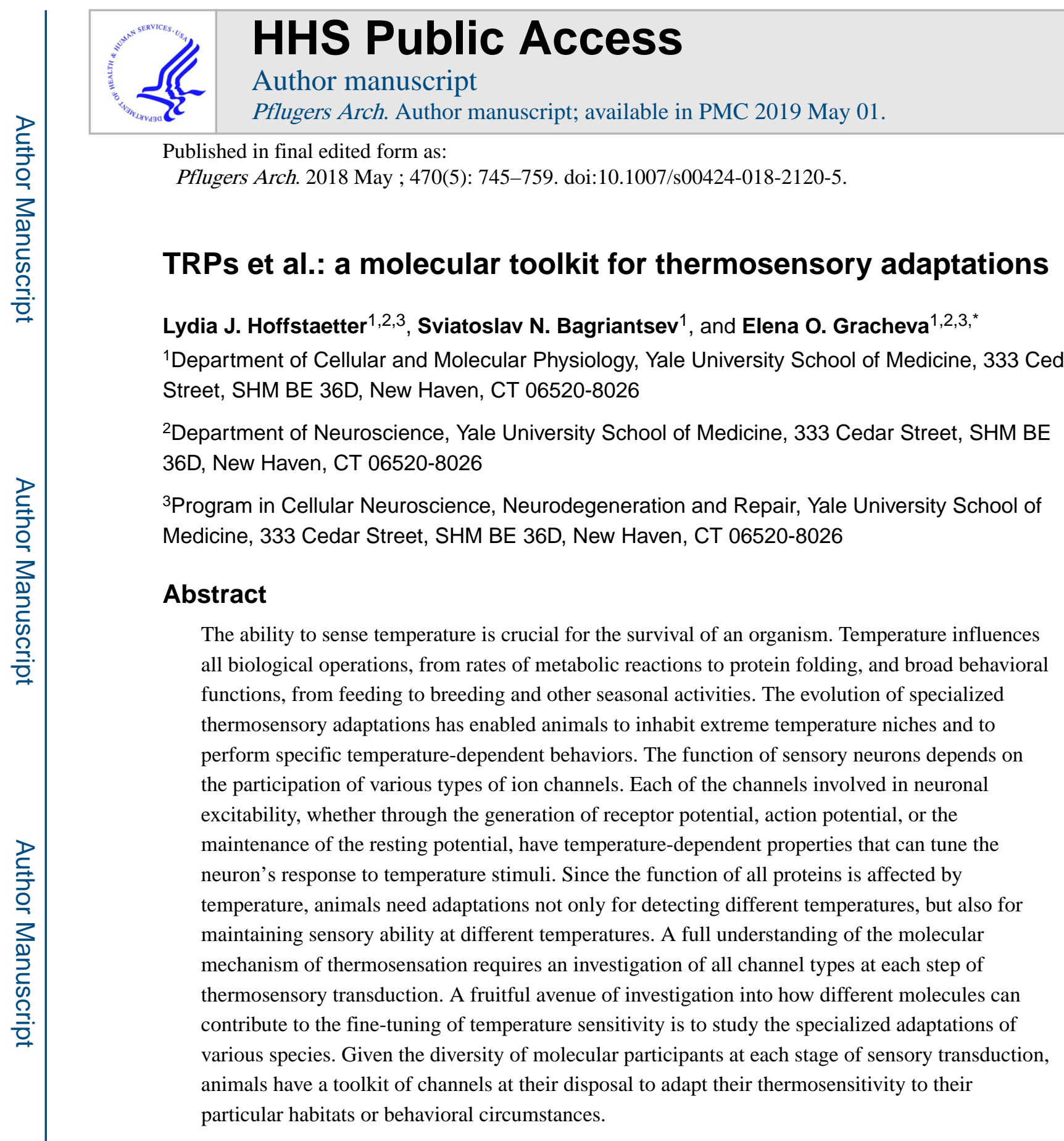

Keywords

Thermosensation; molecular adaptations; ion channels; TRP channels; neuronal excitability

\title{
Introduction
}

Environmental information is detected by sensory primary afferents that innervate the skin, and is transmitted through central projections to the spinal cord and the brain. The cell bodies of the somatosensory neurons reside in the dorsal root ganglia (DRG) that innervate

`address correspondence to: elena.gracheva@yale.edu, Phone: (203) 785-3992 (Elena Gracheva). 
the body, and in trigeminal ganglia (TG) that innervate the face. Somatosensory neurons express a combination of multiple channel types that determine their ability to detect and transmit specific sensory stimuli. Primary sensors generate a graded depolarization in response to a stimulus. The receptor potential activates an inward current through voltagedependent sodium channels to generate the upstroke of an all-or-none action potential. Subsequently, potassium channels conduct an outward current to create the down-stroke and after-hyperpolarization of the action potential. Action potentials are only generated if the cellular depolarization reaches a certain threshold. The proximity of the cell's resting membrane potential to this threshold contributes to how easily the cell can fire in response to stimuli. The resting potential is determined by activities of several types of ion channels and pumps (Fig. 1).

Much attention has been paid to temperature-sensitive receptor channels, but there are a growing number of studies that show that other types of channels play a critical role in the detection and transmission of temperature information. A full understanding of the molecular mechanisms of thermosensation requires an investigation of all channel types at each step of thermosensory transduction. Comparative studies demonstrated that molecular components of the thermosensory system can be altered through evolution to confer temperature adaptions in animals with different thermosensory needs. In this review, we will discuss the involvement of primary temperature sensors, channels that generate and propagate action potential, and channels that maintain the resting potential in regulation of temperature sensitivity across different species.

\section{Primary Temperature Sensors}

A group of temperature-sensitive receptor channels that has been studied extensively is the TRP (transient receptor potential) family (100). TRPs are non-selective cation channels, many of which are polymodal, meaning they generate transient depolarizing potentials in response to multiple types of sensory stimuli. Thus, most of the thermosensitive TRP channels (thermo-TRPs) can be activated by changes in temperature and also by various chemicals, some of which evoke similar temperature-like sensations (61). The activity of the known thermo-TRPs covers the whole range of physiologically relevant temperatures, from painful heat, and intermediate warmth, to cold. For some of the thermo-TRPs, their function in vitro agrees well with their role in the detection of the relevant temperature ranges in sensory neurons and in vivo, while for most such a link has not been firmly established. In addition to thermo-TRPs, a number of other channel types have been shown to be gated by temperature and may play a role in thermosensation.

The temperature-evoked currents of thermo-TRPs increase in a steep but graded manner across their temperature activation range, as the channel open probability increases with changes in temperature. Thermosensitivity is typically quantified using two measures, $\mathrm{Q}_{10}$ and temperature threshold. $\mathrm{Q}_{10}$ refers to the relative change in current amplitude when the temperature increases by 10 degrees. While all reaction rates are dependent on temperature and all channels have a $\mathrm{Q}_{10}$, thermosensors usually have a $\mathrm{Q}_{10}$ of $>5$ (for heat sensors) or $<0.2$ (for cold sensors) (146). By plotting the logarithm of the current response versus the inverse of the temperature in Kelvin (Arrhenius plot, Fig. 2), the $\mathrm{Q}_{10}$ can be calculated from 
the slope of the resulting curve. The intersection of two lines that lie tangent to each end of the Arrhenius plot point at the apparent temperature activation threshold (Fig. 2). However, the temperature threshold should not be misinterpreted as an absolute threshold of channel activation, but rather as a marker of the detectable temperature-sensitive range.

TRPM8

TRPM8 is the receptor for cold temperatures and chemicals that elicit cooling sensation, such as menthol (found in mint leaves) and the synthetic compound icilin $(96,115)$. In cell lines and neurons, mammalian TRPM8 exhibits gradual activation upon cooling below $30^{\circ} \mathrm{C}$. TRPM8 knockout mice show significant deficits in temperature preferences in the cooling range $\left(10^{\circ} \mathrm{C}-20^{\circ} \mathrm{C}\right)$, but retain responses to painful cold below $10^{\circ} \mathrm{C}(17,37)$. Some reports, however, demonstrated deficits in noxious cold sensing even at $5^{\circ} \mathrm{C}(71)$. Genetic or pharmacological ablation of TRPM8-expressing cells, rather than the TRPM8 gene alone, causes deficits in the whole testable cold range $(72,119)$. This indicates that there is an additional TRPM8-independent mechanism for sensing temperatures below $10^{\circ} \mathrm{C}$ (Fig. 3).

Within its role as a cold sensor, there is a diversity of TRPM8 sensitivities among different animal species. When heterologously expressed in oocytes, rat TRPM8 has a half-maximal activation of $24^{\circ} \mathrm{C}$, a few degrees below the rat's preferred ambient temperature of $28^{\circ} \mathrm{C}$ (80). On the other hand, frogs (Xenopus laevis and Xenopus tropicalis) have a notably shifted TRPM8 half-maximal activation to $13.9^{\circ} \mathrm{C}$, which would allow these species to detect cold below their tolerable temperature range of $14^{\circ} \mathrm{C}-32^{\circ} \mathrm{C}(21)$. The half-maximal activation of chicken (Gallus gallus domesticus) TRPM8 is $29.4^{\circ} \mathrm{C}$ (105). For effective cold sensation, it seems that TRPM8 activity is tuned to the relative body temperature of the species. In animals with lower or more variable body temperatures, such as ectothermic animals, whose core body temperature adjusts to ambient levels, it would be detrimental to activate the cold receptor at cool ranges that are frequently experienced (Fig. 4a).

An extreme example of changing body temperature occurs in hibernating animals. Mammals that hibernate exhibit a mixture of endothermic and ectothermic phenotypes, actively maintaining a stable body temperature during the active state, and adjusting body temperature to ambient levels during the torpid state (49). For example, the core body temperature of a thirteen-lined ground squirrel (Ictidomys tridecemlineatus) can drop to $2^{\circ} \mathrm{C}$ $-4^{\circ} \mathrm{C}$ (98), and that of an arctic ground squirrel (Spermophilus undulatus) can drop as low as $-2.9^{\circ} \mathrm{C}$ during hibernation (15). In order to tolerate extended periods of time at such temperatures, these animals must be able to modify their sensation of noxious cold, a sensory mechanism that is not yet fully understood. Furthermore, while transitioning between the active and torpid states, they experience severe hypothermia that would be intolerable to other endothermic animals. The results of a recent study support the possibility that modifications of TRPM8 contribute to cold tolerance in hibernators. The TRPM8 orthologues of two hibernating species, the thirteen-lined ground squirrel and the Syrian hamster (Mesocricetus auratus), respond weakly to cold, especially in the range of $10^{\circ} \mathrm{C}-$ $20^{\circ} \mathrm{C}$, while retaining chemical sensitivity to icilin and menthol. Six amino acids distributed across the transmembrane core of the channel were found to be important for this modality- 
specific modification, and replacing these amino acids with the corresponding residues from the cold-sensitive rat channel is sufficient to restore cold sensitivity in squirrel TRPM8 (95).

\section{TRPA1}

TRPA1 is a polymodal channel that responds to a variety of stimuli in different species (78). A commonly used chemical agonist of TRPA1 is allyl isothiocyanate (AITC), the pungent compound in mustard, radish, horseradish and wasabi $(13,16,26,59)$. TRPA1 can be activated by numerous other noxious chemicals, including naturally derived compounds from cinnamon, garlic, oregano, and olive oil, irritants in smoke and tear gas, and endogenous inflammatory factors. TRPA 1 orthologues of different species have a diversity of functions, which shows the evolutionary flexibility of this molecule (78).

Some, but not all mammalian orthologues of TRPA1 are cold-sensitive (Fig. 3) (28, 75, 97 , 101, 102, 138). Human TRPA1 is activated by cold in a lipid bilayer, suggesting that cold sensitivity is intrinsic to the channel (102). In mice, TRPA1 also mediates physiological sensitivity to cold after injury and in pathological conditions $(36,77)$. In $C$. elegans, TRPA1 is a cold sensor and is required for avoidance of acute cold shock at $15^{\circ} \mathrm{C}(27)$. Moreover, TRPA1 has been implicated in the process of cold-induced longevity in worms (154). Interestingly, deficits in the cold avoidance in TRPA1 knock-out worms could be partially rescued by the mouse orthologue (27). On the other hand, in birds, reptiles, amphibians, and insects, TRPA1 is activated by heat (Fig. 4b) $(51,66,73,123-125,149)$.

The remarkable flexibility of TRPA1 temperature responses might be explained from a thermodynamic standpoint. Thermodynamic considerations dictate that a channel with a sufficiently large change in molar heat capacity between open and closed states will exhibit a steep temperature dependence of its equilibrium constant of opening (31). Furthermore, the equilibrium constant will have a non-linear U-shaped dependence on temperature. It would follow from this that all thermo-TRP's are actually both heat and cold sensors, but only reveal one "arm" of the activation curve in the physiologically testable range. A change in the molecular interactions within the protein could produce a shift in the activation curve along the temperature axis, placing the other arm of the activation curve into the physiological 'window'. This will effectively switch a channel's temperature sensitivity from heat to cold and vice versa, without requiring changes to the temperature sensing elements of the channel (31). Indeed, a U-shaped temperature dependence was shown for human TRPA1, while in mouse TRPA1 the intrinsic directionality of temperature responses can be reversed by a single point mutation (58).

The versatility of TRPA1 makes it a good target for the evolution of specialized functions. Snakes have adapted TRPA1 to detect the heat emission of warm-blooded prey. Three groups of snakes (pit-vipers, boas and pythons) have specialized structures on their facespit organs - that are enriched with TRPA1-expressing trigeminal sensory fibers. The rattlesnake (Crotalus atrox) has the highest sensitivity to infrared radiation. In addition to having a 400-fold higher expression of TRPA1 in TG than in DRG neurons, rattlesnake TRPA1 has a lower apparent heat activation threshold near $28^{\circ} \mathrm{C}$. By comparison, other pitbearing snakes, python (Python regius) and boa (Corallus hortulanus), have thresholds of 
$32.7^{\circ} \mathrm{C}$ and $29.6^{\circ} \mathrm{C}$ respectively, whereas a non-pit snake, Texas rat snake (Elaphe obsoleta lindheimeri)), has a threshold near $37^{\circ} \mathrm{C}$. The increased thermosensitivity of snake TRPA1 channels may come at the expense of chemical sensitivity. Compared to the heat-insensitive rat TRPA1 whose half-maximal effective concentration $\left(\mathrm{EC}_{50}\right)$ for $\mathrm{AITC}$ is $11 \mu \mathrm{M}$, the $\mathrm{EC}_{50}$ of rattlesnake and rat snake is $\geq 500 \mu \mathrm{M}$ (Fig. 4b) (51).

Fruit flies (Drosophila melanogaster) have multiple TRPA1 isoforms, effectively expanding the repertoire of TRPA1 functions. Drosophila TRPA1 (dTRPA1) has been shown to have at least 4 distinct splice isoforms expressed in different sensory organs in order to distinguish between innocuous heat, noxious heat, and noxious chemical stimuli. The dTRPA1-A isoform is activated by the chemical agonist AITC, but shows a very muted temperature response above a threshold of $29.7^{\circ} \mathrm{C}$. dTRPA1-A is expressed in the chemosensors of the proboscis, where it triggers regurgitation upon ingestion of noxious chemicals. Its reduced thermosensitivity avoids regurgitation in response to innocuous heat (65). Another isoform, dTRPA1-B, is activated by temperature with an apparent threshold of $27.8^{\circ} \mathrm{C}$ and various chemical agonists, including AITC. dTRPA1-B has a much steeper response to temperature, with a $\mathrm{Q}_{10}$ of $\sim 116$, compared to dTRPA1-A's $\mathrm{Q}_{10}$ of $\sim 9$. This isoform is expressed only in thermosensors of the fruit fly head where it is secluded from external chemicals. Therefore, dTRPA1-B mainly senses internal and external temperature and is likely responsible for thermal preferences in the innocuous range of $18^{\circ} \mathrm{C}-32^{\circ} \mathrm{C}(65)$. Two additional isoforms, dTRPA1-C and dTRPA1-D, have been shown to contribute to noxious heat sensation. Unlike the dTRPA1-A and B isoforms, dTRPA1-C and D are expressed in neurons that detect painful stimuli that mediate the fly's response to noxious temperatures. However, the apparent properties of these isoforms do not fully explain the fly's noxious heat threshold of $39^{\circ} \mathrm{C}$. dTRPA1-D has a relatively high thermal threshold of $35^{\circ} \mathrm{C}$. dTRPA1-C did not have a detectable thermal response within the testable range up to $42^{\circ} \mathrm{C}$, but is nevertheless required for the typical behavioral response to noxious heat (158).

A possible mechanism for indirect sensation of noxious temperature was recently suggested in a study of planarian flatworms (Schmidtea mediterranea). Planarian TRPA1 is similar to the Drosophila ortholog dTRPA1-C in that it is necessary for avoidance of noxious heat $>30^{\circ} \mathrm{C}$, but it is not directly activated by temperature when expressed heterologously. Instead, it was suggested that its heat-insensitive TRPA1 activates in response to early indicators of tissue damage from heating, such as $\mathrm{H}_{2} \mathrm{O}_{2}$, a known TRPA1 agonist (9).

Drosophila have additional TRPA homologs, Painless and Pyrexia, which are more closely related to basal TRPA's than to the TRPA1 clade (66). By the same phylogenetic analysis, $C$. elegans TRPA1 is also more closely related to basal TRPA's (66). Painless and Pyrexia are activated by noxious heat $(57,81,136,144)$. Additionally, Painless responds to AITC and similar chemicals, and noxious mechanical stimulation $(5,57,144)$. The thermosensory system of flies alone demonstrates several evolutionary mechanisms to create a variety of functional temperature sensors, through gene duplication and through alternative splicing.

Mosquitos (Anopheles gambiae) also use TRPA1 in a crucial thermotaxis behavior. To seek hosts for a blood meal, mosquito females use a variety of cues, including temperature. Their host-seeking thermotaxis involves attraction to warm stimuli, but avoidance of heat that 
exceeds the typical temperature of a host. The avoidance of heat above $50^{\circ} \mathrm{C}$ requires TRPA1 (32). Similar to the fruit fly, mosquitos produce isoforms TRPA1-A and B, with similar chemosensitivity, but much higher thermosensitivity in TRPA1-B (65). These isoforms are conserved in other mosquito species (Aedes aegypti and Culex quinquefasciatus) and lice (Pediculus humanus corporis) (65), demonstrating the evolutionary conservation of this function. Across vertebrates and invertebrates, TRPA1 has a wide range of temperature sensitivities, displaying its evolutionary versatility as a polymodal molecular sensor.

\section{TRPV1}

TRPV1 is a receptor for noxious heat in mammals $\left(>42^{\circ} \mathrm{C}\right)$, as well as for the spicy compound capsaicin (found in hot chili peppers), low $\mathrm{pH}$, and multiple inflammatory mediators $(24,35,61,143)$. TRPV1 knockout mice show significant behavioral deficits in temperature discrimination above $50^{\circ} \mathrm{C}(22)$. However, deletion of TRPV1-positive cells abolishes temperature sensitivity at all testable temperatures above $37^{\circ} \mathrm{C}(99,119)$. This suggests the existence of additional heat sensors in TRPV1-containing neurons (Fig. 3).

The activation of heat sensitive ion channels also appears to correlate with the relative body temperature of different species. In mice and rats, TRPV1 activation occurs several degrees above their core body temperature near $37^{\circ} \mathrm{C}$. Along with birds' higher core body temperature of $41^{\circ} \mathrm{C}-42^{\circ} \mathrm{C}$, chicken TRPV1 has an activation threshold of $>45^{\circ} \mathrm{C}(60)$. In frogs, which are ectothermic and have a much lower preferred temperature range, TRPV1 activation is tuned according to the frog's preferred environment. $X$. tropicalis, which has an optimal temperature range of $22^{\circ} \mathrm{C}-28^{\circ} \mathrm{C}$, has a TRPV1 heat threshold of $38^{\circ} \mathrm{C}$. X. laevis, which has a slightly lower optimal temperature range of $16^{\circ} \mathrm{C}-22^{\circ} \mathrm{C}$, has a TRPV1 heat threshold of $36^{\circ} \mathrm{C}(110)$. Zebrafish (Danio rerio), with a tolerable temperature range of $14^{\circ} \mathrm{C}$ $-33^{\circ} \mathrm{C}$, has an even lower TRPV1 threshold of $32.9^{\circ} \mathrm{C}(50)$. This orthologue is essential for heat avoidance behavior in zebrafish (Fig. 4c) (48).

Animals that live in extremely hot environments also require modifications of TRPV1. Small diurnal rodents, such as ground squirrels and chipmunks, that occupy a wide geographical range from California deserts to Minnesota, can tolerate prolonged heat exposure (56). Consistent with this, ground squirrels do not avoid noxious temperatures up to $55^{\circ} \mathrm{C}$ in a temperature preference test, but they do show nocifensive responses to capsaicin or chili oil. Electrophysiological studies also show that squirrel TRPV1 is sensitive to capsaicin, and $\mathrm{pH}$, but not heat within the testable range up to $48^{\circ} \mathrm{C}$ (79). Another temperature extremophile, the wild Bactrian camel (Camelus ferus), that occupies the Gobi Desert, is faced with a similar problem of surviving high environmental temperature, and has evolved a similar adaptation in TRPV1 to help tolerate these conditions by their somatosensory system (Fig. 4c). Remarkably, TRPV1 sensitivity can be modulated by a single amino acid substitution in both species (79).

Bats have an adaptation to the opposite extreme that makes them especially sensitive to heat. Vampire bats (Desmodus rotundus) feed on the blood of mammals and identify target blood vessels by detecting radiating heat with specialized pit organs, localized on their face (74). 
The specialized function of their pit organs comes from a differentially expressed splice isoform of TRPV1. The truncated (TRPV1-S) isoform is activated at $30^{\circ} \mathrm{C}$ and is expressed exclusively in trigeminal fibers innervating the pit organ, while the full length (TRPV1-L) is activated at $40^{\circ} \mathrm{C}$ and is expressed in the rest of the body. To prevent the constant activation of the TRPV1-S by its own body heat, the pit organs are insulated by a thick layer of tissue (50). The shifting of TRPV1 activation thresholds across species demonstrates the importance of precise heat sensation, and the ability to adapt to a species' specific circumstances (Fig. 4c).

\section{Other thermo-TRPs}

Several other members of the TRP family are considered to be involved in temperature sensitivity. TRPV3 $(52,103,134,155)$, TRPV4 $(53,151)$, and TRPM2 (141) were implicated in sensing intermediate innocuous warmth $\left(25^{\circ} \mathrm{C}-42^{\circ} \mathrm{C}\right)$, TRPM3 (147) noxious heat $\left(>42^{\circ} \mathrm{C}\right)$, TRPV2 $(3,23,85)$-extreme noxious heat $\left(>52^{\circ} \mathrm{C}\right)$, and TRPC5 (160)—innocuous cold $\left(25^{\circ} \mathrm{C}-15^{\circ} \mathrm{C}\right)$. In addition, TRPM5, which is involved in taste perception, is also gated by temperatures spanning the innocuous cool and innocuous warm ranges (140). The temperature sensitivity of some of these channels has been confirmed by knockout studies, such as TRPM3 which caused deficits in noxious heat sensing $(139,147)$, and TRPM2 which altered temperature preference in the innocuous range of $23^{\circ} \mathrm{C}-38^{\circ} \mathrm{C}$ (141). Some thermo-TRPs are interesting candidates for temperature-specific adaptations. For example, TRPV4 mRNA was found to be downregulated in the Japanese grass lizard (Takydromus tachydromoides) in the hibernation state (106). Whether TRPV4 acts as a warm sensor in reptiles is unknown, but the changes of TRPV4 expression may be representative of a general reduction of the thermosensitive components during hibernation.

\section{Other channels}

TRPs are a well-established group of thermosensors, however there are several other temperature sensitive channels that may act as primary sensors or modulators of thermosensitivity. The calcium-activated chloride channel anoctamin (ANO1) depolarizes sensory neurons at temperatures $>44^{\circ} \mathrm{C}$, and deletion of this channel reduces responses to noxious heat (29). Cold temperature activates epithelial sodium channels $(\mathrm{ENaC})$ and potentiates the activity of other members of the DEG/ENaC family (10).

Rhodopsins ( $\mathrm{Rh}$ ), whose canonical function is photodetection, play a role in temperature sensation. In fruit flies, TRPA1 was shown to function downstream of a G-protein coupled signaling cascade (76). Similar to phototransduction in the fruit fly eye, this cascade is initiated by rhodopsins. In mid-third-instar larvae, thermal preference within the tolerable range of $18^{\circ} \mathrm{C}-24^{\circ} \mathrm{C}$ requires $\mathrm{Rh} 1(131)$, while the switch to a strong preference for $18^{\circ} \mathrm{C}$ in late-third-instar larvae requires Rh5 and Rh6 in TRPA1-expressing neurons (135). Rhodopsin-mediated thermotaxis was independent of light, however, it is not yet clear if rhodopsins are intrinsically temperature sensitive.

Recent studies of Drosophila temperature sensitivity also revealed channel paralogs of taste receptors that are involved in thermosensation. The gustatory receptor paralog GR28B(D) is 
activated by heat, and is required for rapid negative thermotaxis, away from high temperatures toward innocuous warmth (107). Interestingly, this channel is expressed in a separate set of neurons from dTRPA1-B and controls a distinct behavior. Several ionotropic receptors (IR), a group that has been well studied in relation to chemosensation, were found to mediate cool sensation and avoidance of cool temperatures. Usually, a modality-specific IR acts in combination with a more widely expressed co-receptor $(1,122)$. IR21a in combination with IR25a and IR93a are responsible for activation of the fruit fly's dorsal organ cold cells (108). However, IR25a and IR93a mediate humidity sensation when expressed in combination with different IR channels $(69,70)$.

C. elegans also illuminates many molecular components of thermosensation, including nonchannel proteins involved in processes such as cGMP signaling and neuron morphology. While TRP channels are involved in the sensation of noxious temperatures in the hot and cold range $(27,86)$, thermotaxis in the innocuous range is mostly mediated by CNG and cGMP channels (8).

This is not an exhaustive list of receptor channels with temperature sensitivity. Other suggested members are the ATP receptor P2X3 $(67,132,137)$, and the calcium channel modulator STIM1 (153), and the list will surely grow to include many more channels in the future. As the multitude of receptor channel types and species-specific adaptations demonstrates, primary temperature sensors are one of the tools available for fine-tuning thermosensitivity.

\section{Action Potential}

Action potential firing depends on two principal types of opposing ion currents. Inward sodium currents rapidly depolarize the cell and generate the upstroke of the action potential. Counteracting the inward currents are outward potassium currents that drive the falling phase of the action potential and repolarize the cell (Fig. 5) (63). Temperature can alter channel properties in multiple ways, such as changing the kinetics of opening and closing, shifting the voltage-dependence of activation and inactivation, which can change the resting potential, input resistance, and electrogenic properties of the cell. Even in neurons that do not express known thermosensitive receptor channels, the transmission of sensory information is affected by temperature. Depending on the ion channel subtypes expressed, and the differential effect of temperature on these channels, various populations of sensory neurons have different responses to changes in temperature $(97,129,145)$.

Observations of excitability in mouse and rat somatosensory neurons at different temperatures demonstrate a diversity of cellular responses to temperature changes. In response to cooling, although most cells were not activated directly by cold, about half of the cells increased their excitability by increasing the number of action potentials fired and/or lowering the rheobase (current threshold) in response to stepwise current injections. Other cells were minimally affected, or decreased their excitability at cold temperatures by decreasing the number of spikes and/or increasing the rheobase $(62,128)$. It is noteworthy that the cells sampled in these studies were mostly small diameter neurons, likely neurons that transmit noxious information, not just of the temperature variety. Cold temperature can 
indeed change the perception of pain, in some cases numbing, in other cases exacerbating it, especially after injury conditions.

\section{Nav1.8}

Nav1.8 is one of several voltage-gated sodium channel (Nav) homologs expressed in dorsal root ganglion neurons. Nav1.8 is resistant to tetrodotoxin (TTX-R), and is a major component of the action potential upstroke in sensory neurons, and is required for robust and sustained action potential firing $(4,152)$. The critical role of Nav1.8 in pain sensation (nociception) is demonstrated by numerous single point mutations in human Nav1.8. Gainof-function mutations lead to severe pain hypersensitivity disorders $(19,44)$.

Studies of sodium currents in sensory neurons at various temperatures have shown that all sodium currents are somewhat reduced and slowed down by cooling $(62,128,159)$. However, compared to the TTX-sensitive Nav1.7 (see below), Nav1.8 is relatively resistant to the effect of cold, with a reduction in current density of only $~ 50 \%$, with a minimal effect on the voltage-dependence of fast and slow inactivation at $10^{\circ} \mathrm{C}$ compared to $30^{\circ} \mathrm{C}(159)$. This has led to the interpretation that Nav1.8 is required for sending cold temperature information, as the main carrier of the action potential. Consistent with this hypothesis, neurons from Nav1.8 knockout mice did not fire action potentials in response to current injections at $10^{\circ} \mathrm{C}$, and knockout mice did not show nocifensive responses to a $0^{\circ} \mathrm{C}$ cold plate (159). Recently, a gain-of-function mutation of Nav1.8, called "Possum," was identified in mice. These animals have severe neurological abnormalities and exhibit significant hypersensitivity to cold when compared to wild-type mice (20).

Nav1.8 is an important evolutionary target for altering the sensitivity of nociceptors. Although an adaptation to temperature specifically has not yet been demonstrated, the case of the grasshopper mouse (Onychomys torridus) shows how alterations in Nav1.8 properties can turn off a pain modality. The grasshopper mouse feeds on the bark scorpion (Centruroides sculpturatus) which can deliver a debilitating painful sting. The toxin in the bark scorpion venom targets a different sodium channel, Nav1.7, to induce pain (91). However, the grasshopper mouse has amino acid variants in Nav1.8 that bind to the bark scorpion toxin and inhibit Nav1.8 activation, thereby stopping the transmission of the pain signal (121).

Other animals might use a similar strategy to alter sensitivity to temperature as well. As noted earlier, hibernators endure extremely cold external and internal temperatures for extended periods of time $(15,98)$. Modifications of Nav1.8 that reduce its activity at cold temperatures could be one mechanism to confer cold tolerance in these animals. For example, in a hibernating snail (Helix pomatia), Nav1.8-like channel expression is downregulated in the central nervous system during the hibernation state. In this mollusk, Nav1.8like currents are also significantly reduced during hibernation (68). As a major contributor to the robust firing of sensory neurons, Nav1.8 is poised to be an evolutionary target to alter sensitivity at the transmission step of thermal signaling. 


\section{Nav1.7}

Nav1.7 is sensitive to inhibition by TTX (TTX-S), and is also a major component of the action potential upstroke. Nav1.7 is frequently co-expressed with Nav1.8 in small diameter DRG neurons $(41,127,142)$. Nav1.7 is activated at more hyperpolarized voltages than Nav1.8, thus Nav1.7 initiates the rapid inward current of an action potential, whereas Nav1.8 is needed to propagate robust, repetitive firing (Fig. 5) (30). Nav1.7 is also critical for nociception, and single point mutations in human Nav1.7 are linked to severe pain hypersensitivity or complete pain insensitivity disorders $(33,34,45,54)$. Several other sodium channels, Nav1.1, Nav1.2, and Nav1.6, are also expressed in some sensory neurons and can contribute to the TTX-S current in DRGs (25). These Nav subtypes may also contribute to nociception, as has been shown for Nav1.1 which has a modality-specific role in mechanical pain but not in thermal pain (111). Total TTX-S current and heterologously expressed Nav1.7 current amplitudes are strongly reduced by cold, by $\sim 90 \%$ at $10^{\circ} \mathrm{C}$ compared to $30^{\circ} \mathrm{C}(159)$. Nav1.7 has a large hyperpolarizing shift in slow inactivation, which could explain the strongly reduced current density in cold temperature at a normal neuronal resting potential near $-80 \mathrm{mV}$ (159). In rat TG and DRG, cells with only TTX-S current usually have a reduced firing rate at cold temperature, firing only a single action potential or several aborted action potentials, which shows that the small amount of remaining TTX-S current cannot support sustained firing $(62,128)$.

Nav1.7 is also an important evolutionary target for the modulation of nociception (157). Although not specifically related to temperature sensation, the African naked mole-rat (Heterocephalus glaber) is an example of a species that uses alterations in Nav1.7 to block a pain modality. Among many interesting features, these animals are resistant to hypoxia, which allows them to live in densely populated underground burrows under high $\mathrm{CO}_{2}$ conditions (112). In many other animals, hypoxia is life threatening and perceived as painful due to the sensation of internal acidification. Instead of changing the function of acid sensors (ASIC's and TRPV1), the naked mole-rat has altered Nav's that are more strongly inhibited by protons. Naked mole-rat sodium currents were decreased by $63 \%$, compared to mouse sodium currents which were decreased by $42 \%$, at $\mathrm{pH}$ 6.0. Although the naked mole-rat's primary acid sensors can depolarize the neuron, signal transduction is blocked at the level of sodium channels and action potential initiation and propagation. This study found that the culprit of this phenomenon is Nav1.7, which has amino acid variants that render this channel more sensitive to block by protons (133).

Similar variants of Nav1.7 were found among other groups of animals that live in high $\mathrm{CO}_{2}$ conditions, including several families of hibernators, which experience internal acidification and high $\mathrm{CO}_{2}$ during torpor due to reduced respiration. However, this was not the case for all hibernators examined (87). For example, the thirteen-lined ground squirrel amino acid residues are more similar to mouse than to naked mole-rat. A similar mechanism could also be responsible for noxious cold tolerance in hibernators, in which increased block of Nav1.7 by cold prevents the propagation of signals in cold-sensitive neurons. Furthermore, action potential block by a pervasive signal such as internal acidification can lead to a more generalized analgesia. In the naked mole-rat, low $\mathrm{pH}$ also blocked other pain modalities, such as mechanically and electrically evoked firing of nociceptors (133). 


\section{Voltage-gated potassium channels}

Several low threshold voltage-gated potassium channels contribute to the falling phase of action potentials. In nociceptors, they are mainly Kv1.4, Kv4.1, Kv4.3 (A-type K+ currents), and KCNQ2/3 (M-type K+ currents) $(18,113,117,120,148,150)$. These channels are involved in modulating the shape of the action potential, membrane repolarization, action potential threshold, and repetitive firing. Since outward potassium currents act in opposition to the inward sodium currents of the rising phase of the action potential, larger potassium currents are thought to restrict neuronal excitability. Both the A- and the M-type currents are reduced and the kinetics are slowed at cold temperature $(62,128)$. The interaction between these currents and different types of sodium channels helps to explain the differential effect of cold on different populations of sensory neurons. In small-diameter somatosensory nociceptors that contain TTX-R sodium currents, which are relatively resistant to cold, the cold-induced reduction of potassium current has the expected result of lifting a brake and increasing the firing rate of these cells. In cells with only TTX-S sodium current, however, the cold-induced slowing of potassium current kinetics has the effect of impairing membrane repolarization which prevents the full recovery from inactivation of the sodium channels, leading to only single firing or aborted action potentials (128).

Cold-induced slowing of potassium channel kinetics that leads to suppression of repetitive firing presents a challenge for species that live in extremely cold habitats. Polar octopi were found to have a very interesting mechanism for altering potassium channel function. Instead of adapting through mutations in the genetic code, the octopi changed the sequence of a Kv1 homolog through RNA editing. Amino acid residues in the pore region were highly edited in an Antarctic octopus (Pareledone sp.), but were mostly unedited in a tropical octopus (Octopus vulgaris). The RNA-edited amino acid changes accelerated the deactivation of the channel, thus shortening the refractory period and increasing repetitive firing. Among 8 different species of octopi, the proportion of edited channels correlated remarkably with the temperature of the species' habitats, pointing to the possibility that this RNA-editing mechanism is temperature dependent (47). The temperature-dependence of the molecular drivers of action potentials can have large effects on an animal's temperature sensitivity, because the blocking of firing can override the activity of temperature sensitive receptor channels. For widely expressed channels that participate in the firing of many different cell types, it is important to maintain functionality at temperatures appropriate to the species' habitat.

\section{Resting Potential}

Another determinant of neuronal excitability is the resting membrane potential. The resting potential is the set-point from which the neuron has to reach the voltage threshold for action potential firing (Fig. 5). A depolarized potential sets the cell closer to the firing threshold, however more depolarized potentials also inactivate more voltage-gated channels, which decrease the cell's ability to fire action potentials. The excitability of a neuron depends on a combination of the expression and availability of different types of channels, the resting membrane potential, the action potential threshold, and other electrogenic properties, such as the input resistance, which represents how easily the membrane potential can be changed. It 
is also crucial to be able to return the cell to the correct membrane potential from the hyperpolarization after an action potential to ensure the continuation of robust firing. Observations in mouse and rat somatosensory neurons showed that the resting potential becomes more depolarized at colder temperatures and that the input resistance increases ( 62 , 128).

The resting potential is determined by the relative concentration of charged particles on each side of the membrane. Several ion channels and pumps that contribute to the distribution of ions across the membrane have been shown to have temperature dependent activity. These include background sodium channels and potassium channels that allow the passive flow of ions along their concentration gradient, and active sodium-potassium pumps that use ATP or sodium gradients to transport the ions against their concentration gradient $(43,46,118)$. Temperature influences the function of these proteins, which can alter the excitability of sensory neurons by changing the set-point at rest or changing the speed of recovery from the after-hyperpolarization.

\section{Nav1.9}

Nav1.9 conducts a persistent inward sodium current at hyperpolarized voltages, and is considered to contribute to setting the resting potential of the cell. Nav1.9 is resistant to TTX and is frequently co-expressed with Nav1.8 in small-diameter DRG neurons $(7,38,40)$. Like Nav1.7 and Nav1.8, Nav1.9 is considered to be crucial for pain sensation (54). There are several single point mutations in human Nav1.9 that are linked to pain disorders, including an interesting gain-of-function mutation that unexpectedly leads to pain insensitivity (39). The mutant channel is hyperactive at the resting potential, causing sustained depolarization that progressively inactivates other Nav's, thus leading to impaired generation of action potentials and aberrant synaptic transmission in nociceptors (83).

As a modulator of neuronal excitability, Nav1.9 was found to be required for sensing noxious cold $(82,90)$. Although Nav1.9 seems not to be a major component in the generation of action potentials, it may act as a subthreshold amplifier of sensory information. Nav1.9 knockout mice have impaired sensation of noxious cold stimuli, without altering temperature responses in the warm range (90). As a modulator of cold sensation, Nav1.9 is another possible evolutionary target for species with noxious cold tolerance. Though an ortholog of this channel was not down-regulated in the hibernating snail (68), the functional properties of this ortholog remain to be investigated, and a potential role in hibernating mammals remains to be determined.

\section{K2P}

Two-pore potassium channels (K2P) provide a voltage-independent potassium leak that is essential for setting the resting membrane potential (42). A greater potassium efflux through these channels hyperpolarizes the membrane and thus suppresses excitability (2). Several members of the K2P family have been shown to be gated by temperature (130). K2P's are also gated by mechanical stimuli and play a role in various sensory processes $(11,12,14,55$, $84,88,89,92,94,114,126)$. 
The main thermosensitive K2P's that have been studied are TREK-1, TREK-2, and TRAAK. These channels are silent at $14^{\circ} \mathrm{C}$ and dramatically increase their activity to a maximum at $>40^{\circ} \mathrm{C}(6,64,93,109,116)$. TREK- 1 and TRAAK are often expressed in TRPV1-positive neurons (156) and act in opposition to the heat-activated TRP channel via elevated potassium leak. In contrast, decreased potassium leak causes neurons to depolarize and is expected to increase excitability. Consistently, TREK- $1^{-/}$, $\mathrm{TRAAK}^{-/}$, or double knockout mice show increased firing of nociceptive fibers, and hypersensitivity to noxious heat $(6,109)$.

Interestingly, deletion of TRAAK alone did not change cold sensitivity, but TREK-1 ${ }^{-/-}$or TREK-1/TRAAK double knockout mice were also hypersensitive to cold (109). This is consistent with the observation that TREK-1, TREK-2 and TRAAK are co-expressed with TRPM8 (156). However, a different K2P, TASK-3, is especially enriched in a population of TRPM8-positive neurons. The deletion of TASK-3 led to increased thresholds and cold hypersensitivity in mice (104). Although TASK-3 had been shown to be only weakly thermosensitive $(12,64)$, it acts as a break on the excitability of cold-sensitive neurons. The ability of channels that regulate the neuronal resting potential to influence the response of temperature sensitive neurons makes them evolutionary targets for thermosensory modifications. Though TREK-1 from thirteen-lined ground squirrels retains temperature sensitivity similar to the mouse ortholog (79), species-specific temperature-dependence of K2P's has not been systematically explored, but they may play an important role in the diversification of thermosensory function.

\section{Conclusion}

The coordinated activity of multiple channel types is required for the transduction and transmission of thermal information. The high number of molecular participants provides a toolkit of adaptable channels for species with different thermosensory needs. The diversity of functions illustrates how each channel can contribute to the tuning of temperature sensitivity relative to optimal temperatures, as seen for TRPM8 and TRPV1 orthologs from mammals, birds, amphibians, and fish. In addition to sensing internal and environmental conditions, TRPs can be adapted for very specialized behavioral functions, such as acute heat sensitivity for hunting in snakes and bats. Sensory modalities can also be tuned independently, as seen in the differences in temperature and chemical sensitivity of TRPA1 between different species, and between splice isoforms of TRPA1 in fruit flies and mosquitos. Aside from the primary temperature sensors, the channels that participate in firing action potentials and setting the neuronal excitability play crucial roles in determining temperature sensitivity. Temperature-dependent changes in the function of voltage-gated sodium, voltage-gated potassium, and potassium leak channels can determine whether or not temperature information is relayed to the central nervous system. Evolutionary examples of Nav adaptations that block pain sensation, as in grasshopper mice and naked-mole rats, may also apply to tolerance of noxious temperatures in certain species. Furthermore, temperaturedependent adaptations may be needed in animals that live in extreme temperature habitats not only for the sensation of temperature, but also for the maintenance of neuronal function, as was illustrated by potassium channels in the polar octopi. A restricted study of only a small number of model species would miss many of the nuanced aspects of channel function 
and adaptability that is revealed by investigating multiple evolutionarily distant species. We expect that future studies will bring to light many more players in the complex molecular machinery of temperature sensation.

\section{Acknowledgments}

This study was partly funded by fellowships from the Beckman Foundation, Rita Allen Foundation and National Institute of Health grant 1R01NS091300-01A1 to E.O.G; by American Heart Association grant 14SDG17880015 and National Science Foundation grant 1453167 to S.N.B; and L.J.H was supported by the National Institute of Health training grant 5T32 HG003198. We would like to thank Jeremy Borjon for his careful reading of this manuscript.

\section{References}

1. Abuin L, Bargeton B, Ulbrich MH, Isacoff EY, Kellenberger S, Benton R. Functional architecture of olfactory ionotropic glutamate receptors. Neuron. 2011; 69:44-60. [PubMed: 21220098]

2. Acosta C, Djouhri L, Watkins R, Berry C, Bromage K, Lawson SN. TREK2 expressed selectively in IB4-binding C-fiber nociceptors hyperpolarizes their membrane potentials and limits spontaneous pain. The Journal of neuroscience: the official journal of the Society for Neuroscience. 2014; 34:1494-1509. [PubMed: 24453337]

3. Ahluwalia J, Rang H, Nagy I. The putative role of vanilloid receptor-like protein-1 in mediating high threshold noxious heat-sensitivity in rat cultured primary sensory neurons. The European journal of neuroscience. 2002; 16:1483-1489. [PubMed: 12405961]

4. Akopian AN, Sivilotti L, Wood JN. A tetrodotoxin-resistant voltage-gated sodium channel expressed by sensory neurons. Nature. 1996; 379:257-262. [PubMed: 8538791]

5. Al-Anzi B, Tracey WD Jr, Benzer S. Response of Drosophila to wasabi is mediated by painless, the fly homolog of mammalian TRPA1/ANKTM1. Current biology: CB. 2006; 16:1034-1040. [PubMed: 16647259]

6. Alloui A, Zimmermann K, Mamet J, Duprat F, Noel J, Chemin J, Guy N, Blondeau N, Voilley N, Rubat-Coudert C, Borsotto M, Romey G, Heurteaux C, Reeh P, Eschalier A, Lazdunski M. TREK-1, a K+ channel involved in polymodal pain perception. The EMBO journal. 2006; 25:23682376. [PubMed: 16675954]

7. Amaya F, Decosterd I, Samad TA, Plumpton C, Tate S, Mannion RJ, Costigan M, Woolf CJ. Diversity of expression of the sensory neuron-specific TTX-resistant voltage-gated sodium ion channels SNS and SNS2. Molecular and cellular neurosciences. 2000; 15:331-342. [PubMed: 10845770]

8. Aoki I, Mori I. Molecular biology of thermosensory transduction in C. elegans. Current opinion in neurobiology. 2015; 34:117-124. [PubMed: 25840145]

9. Arenas OM, Zaharieva EE, Para A, Vásquez-Doorman C, Petersen CP, Gallio M. Activation of planarian TRPA1 by reactive oxygen species reveals a conserved mechanism for animal nociception. Nature neuroscience. 2017

10. Askwith CC, Benson CJ, Welsh MJ, Snyder PM. DEG/ENaC ion channels involved in sensory transduction are modulated by cold temperature. Proceedings of the National Academy of Sciences of the United States of America. 2001; 98:6459-6463. [PubMed: 11353858]

11. Bagriantsev SN, Clark KA, Minor DL Jr. Metabolic and thermal stimuli control K(2P)2.1 (TREK-1) through modular sensory and gating domains. The EMBO journal. 2012; 31:32973308. [PubMed: 22728824]

12. Bagriantsev SN, Peyronnet R, Clark KA, Honore E, Minor DL Jr. Multiple modalities converge on a common gate to control K2P channel function. The EMBO journal. 2011; 30:3594-3606. [PubMed: 21765396]

13. Bandell M, Story GM, Hwang SW, Viswanath V, Eid SR, Petrus MJ, Earley TJ, Patapoutian A. Noxious cold ion channel TRPA1 is activated by pungent compounds and bradykinin. Neuron. 2004; 41:849-857. [PubMed: 15046718] 
14. Bang H, Kim Y, Kim D. TREK-2, a new member of the mechanosensitive tandem-pore K+ channel family. The Journal of biological chemistry. 2000; 275:17412-17419. [PubMed: 10747911]

15. Barger JL, Barnes BM, Boyer BB. Regulation of UCP1 and UCP3 in arctic ground squirrels and relation with mitochondrial proton leak. Journal of applied physiology (Bethesda, Md: 1985). 2006; 101:339-347.

16. Bautista DM, Movahed P, Hinman A, Axelsson HE, Sterner O, Hogestatt ED, Julius D, Jordt SE, Zygmunt PM. Pungent products from garlic activate the sensory ion channel TRPA1. Proceedings of the National Academy of Sciences of the United States of America. 2005; 102:12248-12252. [PubMed: 16103371]

17. Bautista DM, Siemens J, Glazer JM, Tsuruda PR, Basbaum AI, Stucky CL, Jordt SE, Julius D. The menthol receptor TRPM8 is the principal detector of environmental cold. Nature. 2007; 448:204208. [PubMed: 17538622]

18. Benarroch EE. Ion channels in nociceptors: recent developments. Neurology. 2015; 84:1153-1164. [PubMed: 25713000]

19. Bennett DL, Woods CG. Painful and painless channelopathies. The Lancet Neurology. 2014; 13:587-599. [PubMed: 24813307]

20. Blasius AL, Dubin AE, Petrus MJ, Lim BK, Narezkina A, Criado JR, Wills DN, Xia Y, Moresco EM, Ehlers C, Knowlton KU, Patapoutian A, Beutler B. Hypermorphic mutation of the voltagegated sodium channel encoding gene $\mathrm{Scn} 10$ a causes a dramatic stimulus-dependent neurobehavioral phenotype. Proceedings of the National Academy of Sciences of the United States of America. 2011; 108:19413-19418. [PubMed: 22087007]

21. Casterlin ME, Reynolds WW. Diel activity and thermoregulatory behavior of a fully aquatic frog: Xenopus laevis. Hydrobiologia. 1980; 75:189-191.

22. Caterina MJ, Leffler A, Malmberg AB, Martin WJ, Trafton J, Petersen-Zeitz KR, Koltzenburg M, Basbaum AI, Julius D. Impaired nociception and pain sensation in mice lacking the capsaicin receptor. Science (New York, NY). 2000; 288:306-313.

23. Caterina MJ, Rosen TA, Tominaga M, Brake AJ, Julius D. A capsaicin-receptor homologue with a high threshold for noxious heat. Nature. 1999; 398:436-441. [PubMed: 10201375]

24. Caterina MJ, Schumacher MA, Tominaga M, Rosen TA, Levine JD, Julius D. The capsaicin receptor: a heat-activated ion channel in the pain pathway. Nature. 1997; 389:816-824. [PubMed: 9349813]

25. Catterall WA, Goldin AL, Waxman SG. International Union of Pharmacology. XLVII. Nomenclature and structure-function relationships of voltage-gated sodium channels. Pharmacological reviews. 2005; 57:397-409. [PubMed: 16382098]

26. Cavanaugh EJ, Simkin D, Kim D. Activation of transient receptor potential A1 channels by mustard oil, tetrahydrocannabinol and $\mathrm{Ca} 2+$ reveals different functional channel states. Neuroscience. 2008; 154:1467-1476. [PubMed: 18515013]

27. Chatzigeorgiou M, Yoo S, Watson JD, Lee WH, Spencer WC, Kindt KS, Hwang SW, Miller DM 3rd, Treinin M, Driscoll M, Schafer WR. Specific roles for DEG/ENaC and TRP channels in touch and thermosensation in C. elegans nociceptors. Nature neuroscience. 2010; 13:861-868. [PubMed: 20512132]

28. Chen J, Kang D, Xu J, Lake M, Hogan JO, Sun C, Walter K, Yao B, Kim D. Species differences and molecular determinant of TRPA1 cold sensitivity. Nature communications. 2013; 4:2501.

29. Cho H, Yang YD, Lee J, Lee B, Kim T, Jang Y, Back SK, Na HS, Harfe BD, Wang F, Raouf R, Wood JN, Oh U. The calcium-activated chloride channel anoctamin 1 acts as a heat sensor in nociceptive neurons. Nature neuroscience. 2012; 15:1015-1021. [PubMed: 22634729]

30. Choi JS, Waxman SG. Physiological interactions between $\mathrm{Na}(\mathrm{v}) 1.7$ and $\mathrm{Na}(\mathrm{v}) 1.8$ sodium channels: a computer simulation study. Journal of neurophysiology. 2011; 106:3173-3184. [PubMed: 21940606]

31. Clapham DE, Miller C. A thermodynamic framework for understanding temperature sensing by transient receptor potential (TRP) channels. Proceedings of the National Academy of Sciences of the United States of America. 2011; 108:19492-19497. [PubMed: 22109551] 
32. Corfas RA, Vosshall LB. The cation channel TRPA1 tunes mosquito thermotaxis to host temperatures. eLife. 2015; 4

33. Cox JJ, Reimann F, Nicholas AK, Thornton G, Roberts E, Springell K, Karbani G, Jafri H, Mannan J, Raashid Y, Al-Gazali L, Hamamy H, Valente EM, Gorman S, Williams R, McHale DP, Wood JN, Gribble FM, Woods CG. An SCN9A channelopathy causes congenital inability to experience pain. Nature. 2006; 444:894-898. [PubMed: 17167479]

34. Cummins TR, Dib-Hajj SD, Waxman SG. Electrophysiological properties of mutant Nav1.7 sodium channels in a painful inherited neuropathy. The Journal of neuroscience: the official journal of the Society for Neuroscience. 2004; 24:8232-8236. [PubMed: 15385606]

35. Davis JB, Gray J, Gunthorpe MJ, Hatcher JP, Davey PT, Overend P, Harries MH, Latcham J, Clapham C, Atkinson K, Hughes SA, Rance K, Grau E, Harper AJ, Pugh PL, Rogers DC, Bingham S, Randall A, Sheardown SA. Vanilloid receptor-1 is essential for inflammatory thermal hyperalgesia. Nature. 2000; 405:183-187. [PubMed: 10821274]

36. del Camino D, Murphy S, Heiry M, Barrett LB, Earley TJ, Cook CA, Petrus MJ, Zhao M, D’Amours M, Deering N, Brenner GJ, Costigan M, Hayward NJ, Chong JA, Fanger CM, Woolf CJ, Patapoutian A, Moran MM. TRPA1 contributes to cold hypersensitivity. The Journal of neuroscience: the official journal of the Society for Neuroscience. 2010; 30:15165-15174. [PubMed: 21068322]

37. Dhaka A, Murray AN, Mathur J, Earley TJ, Petrus MJ, Patapoutian A. TRPM8 is required for cold sensation in mice. Neuron. 2007; 54:371-378. [PubMed: 17481391]

38. Dib-Hajj S, Black JA, Cummins TR, Waxman SG. NaN/Nav1.9: a sodium channel with unique properties. Trends in neurosciences. 2002; 25:253-259. [PubMed: 11972962]

39. Dib-Hajj SD, Black JA, Waxman SG. NaV1.9: a sodium channel linked to human pain. Nature reviews Neuroscience. 2015; 16:511-519. [PubMed: 26243570]

40. Dib-Hajj SD, Tyrrell L, Black JA, Waxman SG. NaN, a novel voltage-gated Na channel, is expressed preferentially in peripheral sensory neurons and down-regulated after axotomy. Proceedings of the National Academy of Sciences of the United States of America. 1998; 95:8963-8968. [PubMed: 9671787]

41. Djouhri L, Newton R, Levinson SR, Berry CM, Carruthers B, Lawson SN. Sensory and electrophysiological properties of guinea-pig sensory neurones expressing Nav 1.7 (PN1) Na+ channel alpha subunit protein. The Journal of physiology. 2003; 546:565-576. [PubMed: 12527742]

42. Enyedi P, Czirjak G. Molecular background of leak K+ currents: two-pore domain potassium channels. Physiological reviews. 2010; 90:559-605. [PubMed: 20393194]

43. Esmann M, Skou JC. Temperature-dependencies of various catalytic activities of membrane-bound $\mathrm{Na}+\mathrm{K}+-\mathrm{ATPase}$ from ox brain, ox kidney and shark rectal gland and of C12E8-solubilized shark $\mathrm{Na}+\mathrm{K}+-$ ATPase. Biochimica et biophysica acta. 1988; 944:344-350. [PubMed: 2846060]

44. Faber CG, Lauria G, Merkies IS, Cheng X, Han C, Ahn HS, Persson AK, Hoeijmakers JG, Gerrits MM, Pierro T, Lombardi R, Kapetis D, Dib-Hajj SD, Waxman SG. Gain-of-function Nav1.8 mutations in painful neuropathy. Proceedings of the National Academy of Sciences of the United States of America. 2012; 109:19444-19449. [PubMed: 23115331]

45. Fertleman CR, Baker MD, Parker KA, Moffatt S, Elmslie FV, Abrahamsen B, Ostman J, Klugbauer N, Wood JN, Gardiner RM, Rees M. SCN9A mutations in paroxysmal extreme pain disorder: allelic variants underlie distinct channel defects and phenotypes. Neuron. 2006; 52:767774. [PubMed: 17145499]

46. Galarza-Munoz G, Soto-Morales SI, Holmgren M, Rosenthal JJ. Physiological adaptation of an Antarctic Na+/K+-ATPase to the cold. The Journal of experimental biology. 2011; 214:21642174. [PubMed: 21653810]

47. Garrett S, Rosenthal JJ. RNA editing underlies temperature adaptation in $\mathrm{K}+$ channels from polar octopuses. Science (New York, NY). 2012; 335:848-851.

48. Gau P, Poon J, Ufret-Vincenty C, Snelson CD, Gordon SE, Raible DW, Dhaka A. The zebrafish ortholog of TRPV1 is required for heat-induced locomotion. The Journal of neuroscience: the official journal of the Society for Neuroscience. 2013; 33:5249-5260. [PubMed: 23516290]

49. Geiser F. Hibernation. Current biology: CB. 2013; 23:R188-193. [PubMed: 23473557] 
50. Gracheva EO, Cordero-Morales JF, Gonzalez-Carcacia JA, Ingolia NT, Manno C, Aranguren CI, Weissman JS, Julius D. Ganglion-specific splicing of TRPV1 underlies infrared sensation in vampire bats. Nature. 2011; 476:88-91. [PubMed: 21814281]

51. Gracheva EO, Ingolia NT, Kelly YM, Cordero-Morales JF, Hollopeter G, Chesler AT, Sanchez EE, Perez JC, Weissman JS, Julius D. Molecular basis of infrared detection by snakes. Nature. 2010; 464:1006-1011. [PubMed: 20228791]

52. Grandl J, Hu H, Bandell M, Bursulaya B, Schmidt M, Petrus M, Patapoutian A. Pore region of TRPV3 ion channel is specifically required for heat activation. Nature neuroscience. 2008; 11:1007-1013. [PubMed: 19160498]

53. Guler AD, Lee H, Iida T, Shimizu I, Tominaga M, Caterina M. Heat-evoked activation of the ion channel, TRPV4. The Journal of neuroscience: the official journal of the Society for Neuroscience. 2002; 22:6408-6414. [PubMed: 12151520]

54. Hoeijmakers JG, Faber CG, Merkies IS, Waxman SG. Painful peripheral neuropathy and sodium channel mutations. Neuroscience letters. 2015; 596:51-59. [PubMed: 25556685]

55. Honore E, Maingret F, Lazdunski M, Patel AJ. An intracellular proton sensor commands lipid- and mechano-gating of the $\mathrm{K}(+)$ channel TREK-1. The EMBO journal. 2002; 21:2968-2976. [PubMed: 12065410]

56. Hudson JW, Deavers DR. Metabolism, pulmocutaneous water loss and respiration of eight species of ground squirrels from different environments. Comparative biochemistry and physiology A, Comparative physiology. 1973; 45:69-100. [PubMed: 4145712]

57. Hwang RY, Stearns NA, Tracey WD. The ankyrin repeat domain of the TRPA protein painless is important for thermal nociception but not mechanical nociception. PloS one. 2012; 7:e30090. [PubMed: 22295071]

58. Jabba S, Goyal R, Sosa-Pagan JO, Moldenhauer H, Wu J, Kalmeta B, Bandell M, Latorre R, Patapoutian A, Grandl J. Directionality of temperature activation in mouse TRPA1 ion channel can be inverted by single-point mutations in ankyrin repeat six. Neuron. 2014; 82:1017-1031. [PubMed: 24814535]

59. Jordt SE, Bautista DM, Chuang HH, McKemy DD, Zygmunt PM, Hogestatt ED, Meng ID, Julius D. Mustard oils and cannabinoids excite sensory nerve fibres through the TRP channel ANKTM1. Nature. 2004; 427:260-265. [PubMed: 14712238]

60. Jordt SE, Julius D. Molecular basis for species-specific sensitivity to "hot" chili peppers. Cell. 2002; 108:421-430. [PubMed: 11853675]

61. Julius D. TRP channels and pain. Annual review of cell and developmental biology. 2013; 29:355384.

62. Kanda H, Gu JG. Effects of cold temperatures on the excitability of rat trigeminal ganglion neurons that are not for cold sensing. Journal of neurochemistry. 2017; 141:532-543. [PubMed: 26709732]

63. Kandel, ER., Schwartz, JH., Jessell, TM. Principles of neural science. New York: McGraw-Hill, Health Professions Division; 2000.

64. Kang D, Choe C, Kim D. Thermosensitivity of the two-pore domain K+ channels TREK-2 and TRAAK. The Journal of physiology. 2005; 564:103-116. [PubMed: 15677687]

65. Kang K, Panzano VC, Chang EC, Ni L, Dainis AM, Jenkins AM, Regna K, Muskavitch MA, Garrity PA. Modulation of TRPA1 thermal sensitivity enables sensory discrimination in Drosophila. Nature. 2011; 481:76-80. [PubMed: 22139422]

66. Kang K, Pulver SR, Panzano VC, Chang EC, Griffith LC, Theobald DL, Garrity PA. Analysis of Drosophila TRPA1 reveals an ancient origin for human chemical nociception. Nature. 2010; 464:597-600. [PubMed: 20237474]

67. Khmyz V, Maximyuk O, Teslenko V, Verkhratsky A, Krishtal O. P2X3 receptor gating near normal body temperature. Pflugers Archiv: European journal of physiology. 2008; 456:339-347. [PubMed: 18026985]

68. Kiss T, Battonyai I, Pirger Z. Down regulation of sodium channels in the central nervous system of hibernating snails. Physiology \& behavior. 2014; 131:93-98. [PubMed: 24769022]

69. Knecht ZA, Silbering AF, Cruz J, Yang L, Croset V, Benton R, Garrity PA. Ionotropic Receptordependent moist and dry cells control hygrosensation in Drosophila. eLife. 2017; 6 
70. Knecht ZA, Silbering AF, Ni L, Klein M, Budelli G, Bell R, Abuin L, Ferrer AJ, Samuel AD, Benton R, Garrity PA. Distinct combinations of variant ionotropic glutamate receptors mediate thermosensation and hygrosensation in Drosophila. eLife. 2016; 5

71. Knowlton WM, Bifolck-Fisher A, Bautista DM, McKemy DD. TRPM8, but not TRPA1, is required for neural and behavioral responses to acute noxious cold temperatures and cold-mimetics in vivo. Pain. 2010; 150:340-350. [PubMed: 20542379]

72. Knowlton WM, Palkar R, Lippoldt EK, McCoy DD, Baluch F, Chen J, McKemy DD. A sensorylabeled line for cold: TRPM8-expressing sensory neurons define the cellular basis for cold, cold pain, and cooling-mediated analgesia. The Journal of neuroscience: the official journal of the Society for Neuroscience. 2013; 33:2837-2848. [PubMed: 23407943]

73. Kurganov E, Zhou Y, Saito S, Tominaga M. Heat and AITC activate green anole TRPA1 in a membrane-delimited manner. Pflugers Archiv: European journal of physiology. 2014; 466:18731884. [PubMed: 24385018]

74. Kürten L, Schmidt U. Thermoperception in the common vampire bat (Desmodus rotundus). Journal of comparative physiology. 1982; 146:223-228.

75. Kwan KY, Allchorne AJ, Vollrath MA, Christensen AP, Zhang DS, Woolf CJ, Corey DP. TRPA1 contributes to cold, mechanical, and chemical nociception but is not essential for hair-cell transduction. Neuron. 2006; 50:277-289. [PubMed: 16630838]

76. Kwon Y, Shim HS, Wang X, Montell C. Control of thermotactic behavior via coupling of a TRP channel to a phospholipase C signaling cascade. Nature neuroscience. 2008; 11:871-873. [PubMed: 18660806]

77. Laing RJ, Dhaka A. ThermoTRPs and Pain. The Neuroscientist: a review journal bringing neurobiology, neurology and psychiatry. 2016; 22:171-187.

78. Laursen WJ, Anderson EO, Hoffstaetter LJ, Bagriantsev SN, Gracheva EO. Species-specific temperature sensitivity of TRPA1. Temperature (Austin, Tex). 2015; 2:214-226.

79. Laursen WJ, Schneider ER, Merriman DK, Bagriantsev SN, Gracheva EO. Low-cost functional plasticity of TRPV1 supports heat tolerance in squirrels and camels. Proceedings of the National Academy of Sciences of the United States of America. 2016; 113:11342-11347. [PubMed: 27638213]

80. Lee H, Iida T, Mizuno A, Suzuki M, Caterina MJ. Altered thermal selection behavior in mice lacking transient receptor potential vanilloid 4. The Journal of neuroscience: the official journal of the Society for Neuroscience. 2005; 25:1304-1310. [PubMed: 15689568]

81. Lee Y, Lee Y, Lee J, Bang S, Hyun S, Kang J, Hong ST, Bae E, Kaang BK, Kim J. Pyrexia is a new thermal transient receptor potential channel endowing tolerance to high temperatures in Drosophila melanogaster. Nature genetics. 2005; 37:305-310. [PubMed: 15731759]

82. Leipold E, Hanson-Kahn A, Frick M, Gong P, Bernstein JA, Voigt M, Katona I, Oliver Goral R, Altmuller J, Nurnberg P, Weis J, Hubner CA, Heinemann SH, Kurth I. Cold-aggravated pain in humans caused by a hyperactive NaV1.9 channel mutant. Nature communications. 2015; 6:10049.

83. Leipold E, Liebmann L, Korenke GC, Heinrich T, Giesselmann S, Baets J, Ebbinghaus M, Goral RO, Stodberg T, Hennings JC, Bergmann M, Altmuller J, Thiele H, Wetzel A, Nurnberg P, Timmerman V, De Jonghe P, Blum R, Schaible HG, Weis J, Heinemann SH, Hubner CA, Kurth I. A de novo gain-of-function mutation in SCN11A causes loss of pain perception. Nature genetics. 2013; 45:1399-1404. [PubMed: 24036948]

84. Lesage F, Terrenoire C, Romey G, Lazdunski M. Human TREK2, a 2P domain mechano-sensitive $\mathrm{K}+$ channel with multiple regulations by polyunsaturated fatty acids, lysophospholipids, and Gs, $\mathrm{Gi}$, and Gq protein-coupled receptors. The Journal of biological chemistry. 2000; 275:2839828405. [PubMed: 10880510]

85. Liu B, Qin F. Use Dependence of Heat Sensitivity of Vanilloid Receptor TRPV2. Biophys J. 2016; 110:1523-1537. [PubMed: 27074678]

86. Liu S, Schulze E, Baumeister R. Temperature- and touch-sensitive neurons couple CNG and TRPV channel activities to control heat avoidance in Caenorhabditis elegans. PloS one. 2012; 7:e32360. [PubMed: 22448218] 
87. Liu Z, Wang W, Zhang TZ, Li GH, He K, Huang JF, Jiang XL, Murphy RW, Shi P. Repeated functional convergent effects of $\mathrm{NaV} 1.7$ on acid insensitivity in hibernating mammals. Proceedings Biological sciences. 2014; 281:20132950. [PubMed: 24352952]

88. Lolicato M, Arrigoni C, Mori T, Sekioka Y, Bryant C, Clark KA, Minor DL Jr. K2P2.1 (TREK-1)activator complexes reveal a cryptic selectivity filter binding site. Nature. 2017; 547:364-368. [PubMed: 28693035]

89. Lolicato M, Riegelhaupt PM, Arrigoni C, Clark KA, Minor DL Jr. Transmembrane helix straightening and buckling underlies activation of mechanosensitive and thermosensitive $\mathrm{K}(2 \mathrm{P})$ channels. Neuron. 2014; 84:1198-1212. [PubMed: 25500157]

90. Lolignier S, Bonnet C, Gaudioso C, Noel J, Ruel J, Amsalem M, Ferrier J, Rodat-Despoix L, Bouvier V, Aissouni Y, Prival L, Chapuy E, Padilla F, Eschalier A, Delmas P, Busserolles J. The Nav1.9 channel is a key determinant of cold pain sensation and cold allodynia. Cell reports. 2015; 11:1067-1078. [PubMed: 25959819]

91. Maertens C, Cuypers E, Amininasab M, Jalali A, Vatanpour H, Tytgat J. Potent modulation of the voltage-gated sodium channel Nav1.7 by OD1, a toxin from the scorpion Odonthobuthus doriae. Molecular pharmacology. 2006; 70:405-414. [PubMed: 16641312]

92. Maingret F, Fosset M, Lesage F, Lazdunski M, Honore E. TRAAK is a mammalian neuronal mechano-gated K+ channel. The Journal of biological chemistry. 1999; 274:1381-1387. [PubMed: 9880510]

93. Maingret F, Lauritzen I, Patel AJ, Heurteaux C, Reyes R, Lesage F, Lazdunski M, Honore E. TREK-1 is a heat-activated background $\mathrm{K}(+)$ channel. The EMBO journal. 2000; 19:2483-2491. [PubMed: 10835347]

94. Maingret F, Patel AJ, Lesage F, Lazdunski M, Honore E. Mechano- or acid stimulation, two interactive modes of activation of the TREK-1 potassium channel. The Journal of biological chemistry. 1999; 274:26691-26696. [PubMed: 10480871]

95. Matos-Cruz V, Schneider ER, Mastrotto M, Merriman DK, Bagriantsev SN, Gracheva EO. Molecular Prerequisites for Diminished Cold Sensitivity in Ground Squirrels and Hamsters. Cell reports. 21:3329-3337.

96. McKemy DD, Neuhausser WM, Julius D. Identification of a cold receptor reveals a general role for TRP channels in thermosensation. Nature. 2002; 416:52-58. [PubMed: 11882888]

97. Memon T, Chase K, Leavitt LS, Olivera BM, Teichert RW. TRPA1 expression levels and excitability brake by KV channels influence cold sensitivity of TRPA1-expressing neurons. Neuroscience. 2017; 353:76-86. [PubMed: 28408328]

98. Merriman DK, Lahvis G, Jooss M, Gesicki JA, Schill K. Current practices in a captive breeding colony of 13-lined ground squirrels (Ictidomys tridecemlineatus). Lab animal. 2012; 41:315-325. [PubMed: 23079915]

99. Mishra SK, Tisel SM, Orestes P, Bhangoo SK, Hoon MA. TRPV1-lineage neurons are required for thermal sensation. The EMBO journal. 2011; 30:582-593. [PubMed: 21139565]

100. Montell C, Birnbaumer L, Flockerzi V, Bindels RJ, Bruford EA, Caterina MJ, Clapham DE, Harteneck C, Heller S, Julius D, Kojima I, Mori Y, Penner R, Prawitt D, Scharenberg AM, Schultz G, Shimizu N, Zhu MX. A unified nomenclature for the superfamily of TRP cation channels. Molecular cell. 2002; 9:229-231. [PubMed: 11864597]

101. Moparthi L, Kichko TI, Eberhardt M, Hogestatt ED, Kjellbom P, Johanson U, Reeh PW, Leffler A, Filipovic MR, Zygmunt PM. Human TRPA1 is a heat sensor displaying intrinsic U-shaped thermosensitivity. Scientific reports. 2016; 6:28763. [PubMed: 27349477]

102. Moparthi L, Survery S, Kreir M, Simonsen C, Kjellbom P, Hogestatt ED, Johanson U, Zygmunt PM. Human TRPA1 is intrinsically cold- and chemosensitive with and without its N-terminal ankyrin repeat domain. Proceedings of the National Academy of Sciences of the United States of America. 2014; 111:16901-16906. [PubMed: 25389312]

103. Moqrich A, Hwang SW, Earley TJ, Petrus MJ, Murray AN, Spencer KS, Andahazy M, Story GM, Patapoutian A. Impaired thermosensation in mice lacking TRPV3, a heat and camphor sensor in the skin. Science (New York, NY). 2005; 307:1468-1472. 
104. Morenilla-Palao C, Luis E, Fernandez-Pena C, Quintero E, Weaver JL, Bayliss DA, Viana F. Ion channel profile of TRPM8 cold receptors reveals a role of TASK-3 potassium channels in thermosensation. Cell reports. 2014; 8:1571-1582. [PubMed: 25199828]

105. Myers BR, Sigal YM, Julius D. Evolution of thermal response properties in a cold-activated TRP channel. PloS one. 2009; 4:e5741. [PubMed: 19492038]

106. Nagai K, Saitoh Y, Saito S, Tsutsumi K. Structure and hibernation-associated expression of the transient receptor potential vanilloid 4 channel (TRPV4) mRNA in the Japanese grass lizard (Takydromus tachydromoides). Zoological science. 2012; 29:185-190. [PubMed: 22379986]

107. Ni L, Bronk P, Chang EC, Lowell AM, Flam JO, Panzano VC, Theobald DL, Griffith LC, Garrity PA. A gustatory receptor paralogue controls rapid warmth avoidance in Drosophila. Nature. 2013; 500:580-584. [PubMed: 23925112]

108. Ni L, Klein M, Svec KV, Budelli G, Chang EC, Ferrer AJ, Benton R, Samuel AD, Garrity PA. The Ionotropic Receptors IR21a and IR25a mediate cool sensing in Drosophila. eLife. 2016; 5

109. Noel J, Zimmermann K, Busserolles J, Deval E, Alloui A, Diochot S, Guy N, Borsotto M, Reeh P, Eschalier A, Lazdunski M. The mechano-activated K+ channels TRAAK and TREK-1 control both warm and cold perception. The EMBO journal. 2009; 28:1308-1318. [PubMed: 19279663]

110. Ohkita M, Saito S, Imagawa T, Takahashi K, Tominaga M, Ohta T. Molecular cloning and functional characterization of Xenopus tropicalis frog transient receptor potential vanilloid 1 reveal its functional evolution for heat, acid, and capsaicin sensitivities in terrestrial vertebrates. The Journal of biological chemistry. 2012; 287:2388-2397. [PubMed: 22130664]

111. Osteen JD, Herzig V, Gilchrist J, Emrick JJ, Zhang C, Wang X, Castro J, Garcia-Caraballo S, Grundy L, Rychkov GY, Weyer AD, Dekan Z, Undheim EA, Alewood P, Stucky CL, Brierley SM, Basbaum AI, Bosmans F, King GF, Julius D. Selective spider toxins reveal a role for the Nav1.1 channel in mechanical pain. Nature. 2016; 534:494-499. [PubMed: 27281198]

112. Park TJ, Reznick J, Peterson BL, Blass G, Omerbasic D, Bennett NC, Kuich P, Zasada C, Browe BM, Hamann W, Applegate DT, Radke MH, Kosten T, Lutermann H, Gavaghan V, Eigenbrod O, Begay V, Amoroso VG, Govind V, Minshall RD, Smith ESJ, Larson J, Gotthardt M, Kempa S, Lewin GR. Fructose-driven glycolysis supports anoxia resistance in the naked mole-rat. Science (New York, NY). 2017; 356:307-311.

113. Passmore GM, Selyanko AA, Mistry M, Al-Qatari M, Marsh SJ, Matthews EA, Dickenson AH, Brown TA, Burbidge SA, Main M, Brown DA. KCNQ/M currents in sensory neurons: significance for pain therapy. The Journal of neuroscience: the official journal of the Society for Neuroscience. 2003; 23:7227-7236. [PubMed: 12904483]

114. Patel AJ, Honore E, Maingret F, Lesage F, Fink M, Duprat F, Lazdunski M. A mammalian two pore domain mechano-gated S-like K+ channel. The EMBO journal. 1998; 17:4283-4290. [PubMed: 9687497]

115. Peier AM, Moqrich A, Hergarden AC, Reeve AJ, Andersson DA, Story GM, Earley TJ, Dragoni I, McIntyre P, Bevan S, Patapoutian A. A TRP channel that senses cold stimuli and menthol. Cell. 2002; 108:705-715. [PubMed: 11893340]

116. Pereira V, Busserolles J, Christin M, Devilliers M, Poupon L, Legha W, Alloui A, Aissouni Y, Bourinet E, Lesage F, Eschalier A, Lazdunski M, Noel J. Role of the TREK2 potassium channel in cold and warm thermosensation and in pain perception. Pain. 2014; 155:2534-2544. [PubMed: 25239074]

117. Phuket TR, Covarrubias M. Kv4 Channels Underlie the Subthreshold-Operating A-type K-current in Nociceptive Dorsal Root Ganglion Neurons. Frontiers in molecular neuroscience. 2009; 2:3. [PubMed: 19668710]

118. Pierau FK, Torrey P, Carpenter DO. Mammalian cold receptor afferents: role of an electrogenic sodium pump in sensory transduction. Brain research. 1974; 73:156-160. [PubMed: 4407843]

119. Pogorzala LA, Mishra SK, Hoon MA. The cellular code for mammalian thermosensation. The Journal of neuroscience: the official journal of the Society for Neuroscience. 2013; 33:55335541. [PubMed: 23536068]

120. Rasband MN, Park EW, Vanderah TW, Lai J, Porreca F, Trimmer JS. Distinct potassium channels on pain-sensing neurons. Proceedings of the National Academy of Sciences of the United States of America. 2001; 98:13373-13378. [PubMed: 11698689] 
121. Rowe AH, Xiao Y, Rowe MP, Cummins TR, Zakon HH. Voltage-gated sodium channel in grasshopper mice defends against bark scorpion toxin. Science (New York, NY). 2013; 342:441446.

122. Rytz R, Croset V, Benton R. Ionotropic receptors (IRs): chemosensory ionotropic glutamate receptors in Drosophila and beyond. Insect biochemistry and molecular biology. 2013; 43:888897. [PubMed: 23459169]

123. Saito S, Banzawa N, Fukuta N, Saito CT, Takahashi K, Imagawa T, Ohta T, Tominaga M. Heat and noxious chemical sensor, chicken TRPA1, as a target of bird repellents and identification of its structural determinants by multispecies functional comparison. Molecular biology and evolution. 2014; 31:708-722. [PubMed: 24398321]

124. Saito S, Nakatsuka K, Takahashi K, Fukuta N, Imagawa T, Ohta T, Tominaga M. Analysis of transient receptor potential ankyrin 1 (TRPA1) in frogs and lizards illuminates both nociceptive heat and chemical sensitivities and coexpression with TRP vanilloid 1 (TRPV1) in ancestral vertebrates. The Journal of biological chemistry. 2012; 287:30743-30754. [PubMed: 22791718]

125. Saito S, Ohkita M, Saito CT, Takahashi K, Tominaga M, Ohta T. Evolution of Heat Sensors Drove Shifts in Thermosensation between Xenopus Species Adapted to Different Thermal Niches. The Journal of biological chemistry. 2016; 291:11446-11459. [PubMed: 27022021]

126. Sandoz G, Douguet D, Chatelain F, Lazdunski M, Lesage F. Extracellular acidification exerts opposite actions on TREK1 and TREK2 potassium channels via a single conserved histidine residue. Proceedings of the National Academy of Sciences of the United States of America. 2009; 106:14628-14633. [PubMed: 19667202]

127. Sangameswaran L, Fish LM, Koch BD, Rabert DK, Delgado SG, Ilnicka M, Jakeman LB, Novakovic S, Wong K, Sze P, Tzoumaka E, Stewart GR, Herman RC, Chan H, Eglen RM, Hunter JC. A novel tetrodotoxin-sensitive, voltage-gated sodium channel expressed in rat and human dorsal root ganglia. The Journal of biological chemistry. 1997; 272:14805-14809. [PubMed: 9169448]

128. Sarria I, Ling J, Gu JG. Thermal sensitivity of voltage-gated Na+ channels and A-type K+ channels contributes to somatosensory neuron excitability at cooling temperatures. Journal of neurochemistry. 2012; 122:1145-1154. [PubMed: 22712529]

129. Sarria I, Ling J, Xu GY, Gu JG. Sensory discrimination between innocuous and noxious cold by TRPM8-expressing DRG neurons of rats. Molecular pain. 2012; 8:79. [PubMed: 23092296]

130. Schneider ER, Anderson EO, Gracheva EO, Bagriantsev SN. Temperature sensitivity of two-pore (K2P) potassium channels. Current topics in membranes. 2014; 74:113-133. [PubMed: 25366235]

131. Shen WL, Kwon Y, Adegbola AA, Luo J, Chess A, Montell C. Function of rhodopsin in temperature discrimination in Drosophila. Science (New York, NY). 2011; 331:1333-1336.

132. Shimizu I, Iida T, Guan Y, Zhao C, Raja SN, Jarvis MF, Cockayne DA, Caterina MJ. Enhanced thermal avoidance in mice lacking the ATP receptor P2X3. Pain. 2005; 116:96-108. [PubMed: 15927378]

133. Smith ES, Omerbasic D, Lechner SG, Anirudhan G, Lapatsina L, Lewin GR. The molecular basis of acid insensitivity in the African naked mole-rat. Science (New York, NY). 2011; 334:15571560.

134. Smith GD, Gunthorpe MJ, Kelsell RE, Hayes PD, Reilly P, Facer P, Wright JE, Jerman JC, Walhin JP, Ooi L, Egerton J, Charles KJ, Smart D, Randall AD, Anand P, Davis JB. TRPV3 is a temperature-sensitive vanilloid receptor-like protein. Nature. 2002; 418:186-190. [PubMed: 12077606]

135. Sokabe T, Chen HC, Luo J, Montell C. A Switch in Thermal Preference in Drosophila Larvae Depends on Multiple Rhodopsins. Cell reports. 2016; 17:336-344. [PubMed: 27705783]

136. Sokabe T, Tsujiuchi S, Kadowaki T, Tominaga M. Drosophila painless is a Ca2+-requiring channel activated by noxious heat. The Journal of neuroscience: the official journal of the Society for Neuroscience. 2008; 28:9929-9938. [PubMed: 18829951]

137. Souslova V, Cesare P, Ding Y, Akopian AN, Stanfa L, Suzuki R, Carpenter K, Dickenson A, Boyce S, Hill R, Nebenuis-Oosthuizen D, Smith AJ, Kidd EJ, Wood JN. Warm-coding deficits 
and aberrant inflammatory pain in mice lacking P2X3 receptors. Nature. 2000; 407:1015-1017. [PubMed: 11069182]

138. Story GM, Peier AM, Reeve AJ, Eid SR, Mosbacher J, Hricik TR, Earley TJ, Hergarden AC, Andersson DA, Hwang SW, McIntyre P, Jegla T, Bevan S, Patapoutian A. ANKTM1, a TRP-like channel expressed in nociceptive neurons, is activated by cold temperatures. Cell. 2003; 112:819-829. [PubMed: 12654248]

139. Straub I, Krugel U, Mohr F, Teichert J, Rizun O, Konrad M, Oberwinkler J, Schaefer M. Flavanones that selectively inhibit TRPM3 attenuate thermal nociception in vivo. Molecular pharmacology. 2013; 84:736-750. [PubMed: 24006495]

140. Talavera K, Yasumatsu K, Voets T, Droogmans G, Shigemura N, Ninomiya Y, Margolskee RF, Nilius B. Heat activation of TRPM5 underlies thermal sensitivity of sweet taste. Nature. 2005; 438:1022-1025. [PubMed: 16355226]

141. Tan $\mathrm{CH}, \mathrm{McNaughton} \mathrm{PA}$. The TRPM2 ion channel is required for sensitivity to warmth. Nature. 2016; 536:460-463. [PubMed: 27533035]

142. Toledo-Aral JJ, Moss BL, He ZJ, Koszowski AG, Whisenand T, Levinson SR, Wolf JJ, SilosSantiago I, Halegoua S, Mandel G. Identification of PN1, a predominant voltage-dependent sodium channel expressed principally in peripheral neurons. Proceedings of the National Academy of Sciences of the United States of America. 1997; 94:1527-1532. [PubMed: 9037087]

143. Tominaga M, Caterina MJ, Malmberg AB, Rosen TA, Gilbert H, Skinner K, Raumann BE, Basbaum AI, Julius D. The cloned capsaicin receptor integrates multiple pain-producing stimuli. Neuron. 1998; 21:531-543. [PubMed: 9768840]

144. Tracey WD Jr, Wilson RI, Laurent G, Benzer S. painless, a Drosophila gene essential for nociception. Cell. 2003; 113:261-273. [PubMed: 12705873]

145. Viana F, de la Pena E, Belmonte C. Specificity of cold thermotransduction is determined by differential ionic channel expression. Nature neuroscience. 2002; 5:254-260. [PubMed: 11836533]

146. Voets T. Quantifying and modeling the temperature-dependent gating of TRP channels. Reviews of physiology, biochemistry and pharmacology. 2012; 162:91-119.

147. Vriens J, Owsianik G, Hofmann T, Philipp SE, Stab J, Chen X, Benoit M, Xue F, Janssens A, Kerselaers S, Oberwinkler J, Vennekens R, Gudermann T, Nilius B, Voets T. TRPM3 is a nociceptor channel involved in the detection of noxious heat. Neuron. 2011; 70:482-494. [PubMed: 21555074]

148. Vydyanathan A, Wu ZZ, Chen SR, Pan HL. A-type voltage-gated K+ currents influence firing properties of isolectin B4-positive but not isolectin B4-negative primary sensory neurons. Journal of neurophysiology. 2005; 93:3401-3409. [PubMed: 15647393]

149. Wang G, Qiu YT, Lu T, Kwon HW, Pitts RJ, Van Loon JJ, Takken W, Zwiebel LJ. Anopheles gambiae TRPA1 is a heat-activated channel expressed in thermosensitive sensilla of female antennae. The European journal of neuroscience. 2009; 30:967-974. [PubMed: 19735290]

150. Wang HS, Pan Z, Shi W, Brown BS, Wymore RS, Cohen IS, Dixon JE, McKinnon D. KCNQ2 and KCNQ3 potassium channel subunits: molecular correlates of the M-channel. Science (New York, NY). 1998; 282:1890-1893.

151. Watanabe H, Vriens J, Suh SH, Benham CD, Droogmans G, Nilius B. Heat-evoked activation of TRPV4 channels in a HEK293 cell expression system and in native mouse aorta endothelial cells. The Journal of biological chemistry. 2002; 277:47044-47051. [PubMed: 12354759]

152. Waxman SG, Zamponi GW. Regulating excitability of peripheral afferents: emerging ion channel targets. Nature neuroscience. 2014; 17:153-163. [PubMed: 24473263]

153. Xiao B, Coste B, Mathur J, Patapoutian A. Temperature-dependent STIM1 activation induces $\mathrm{Ca}(2)+$ influx and modulates gene expression. Nature chemical biology. 2011; 7:351-358. [PubMed: 21499266]

154. Xiao R, Zhang B, Dong Y, Gong J, Xu T, Liu J, Xu XZ. A genetic program promotes C. elegans longevity at cold temperatures via a thermosensitive TRP channel. Cell. 2013; 152:806-817. [PubMed: 23415228] 
155. Xu H, Ramsey IS, Kotecha SA, Moran MM, Chong JA, Lawson D, Ge P, Lilly J, Silos-Santiago I, Xie Y, DiStefano PS, Curtis R, Clapham DE. TRPV3 is a calcium-permeable temperaturesensitive cation channel. Nature. 2002; 418:181-186. [PubMed: 12077604]

156. Yamamoto Y, Hatakeyama T, Taniguchi K. Immunohistochemical colocalization of TREK-1, TREK-2 and TRAAK with TRP channels in the trigeminal ganglion cells. Neuroscience letters. 2009; 454:129-133. [PubMed: 19429069]

157. Zakon HH. Adaptive evolution of voltage-gated sodium channels: the first 800 million years. Proceedings of the National Academy of Sciences of the United States of America. 2012; 109(Suppl 1):10619-10625. [PubMed: 22723361]

158. Zhong L, Bellemer A, Yan H, Ken H, Jessica R, Hwang RY, Pitt GS, Tracey WD. Thermosensory and nonthermosensory isoforms of Drosophila melanogaster TRPA1 reveal heat-sensor domains of a thermoTRP Channel. Cell reports. 2012; 1:43-55. [PubMed: 22347718]

159. Zimmermann K, Leffler A, Babes A, Cendan CM, Carr RW, Kobayashi J, Nau C, Wood JN, Reeh PW. Sensory neuron sodium channel Nav1.8 is essential for pain at low temperatures. Nature. 2007; 447:855-858. [PubMed: 17568746]

160. Zimmermann K, Lennerz JK, Hein A, Link AS, Kaczmarek JS, Delling M, Uysal S, Pfeifer JD, Riccio A, Clapham DE. Transient receptor potential cation channel, subfamily C, member 5 (TRPC5) is a cold-transducer in the peripheral nervous system. Proceedings of the National Academy of Sciences of the United States of America. 2011; 108:18114-18119. [PubMed: 22025699] 


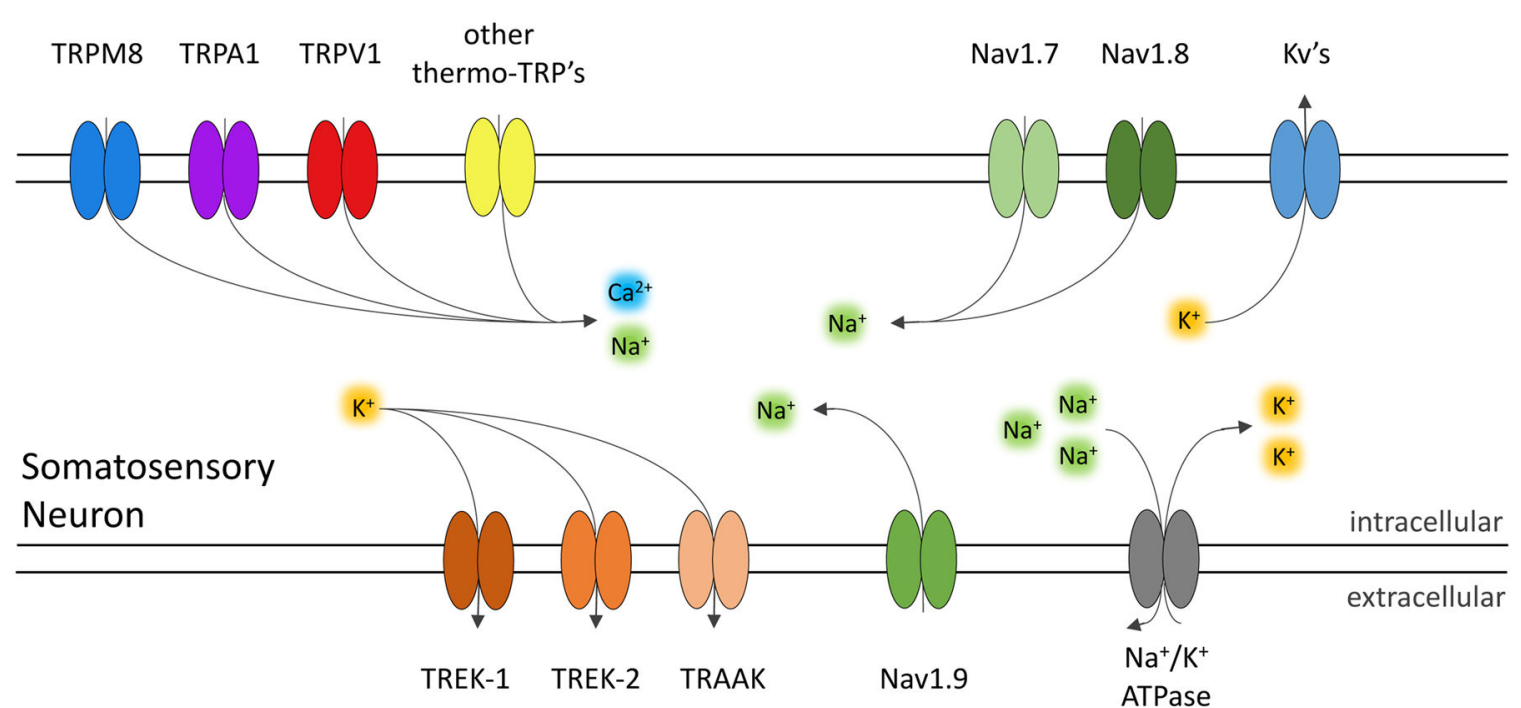

Resting potential

Figure 1. Diagram of molecular participants in thermosensory excitability

Multiple channel types contribute to the function of thermosensory neurons. Primary sensors of temperature are non-specific cation channels (TRPM8, TRPA1, TRPM8, and other thermo-TRP's). Action potentials in thermosensitive neurons are mainly conducted by voltage-gated sodium channels (Nav1.7 and Nav1.8) which promote excitability. Voltagegated potassium channels (Kv's) provide a counteracting current that limits excitability. Nav1.9 is a regulator of the resting potential and amplifier of subthreshold depolarization. The resting potential of thermosensory neurons is also regulated by thermo-sensitive leak potassium channels (TREK-1, TREK-2, and TRAAK) which counteract excitability. Another contributor to the resting potential is the $\mathrm{Na}^{+} / \mathrm{K}^{+}$-ATPase, which sets up the ionic gradients across the membrane. 


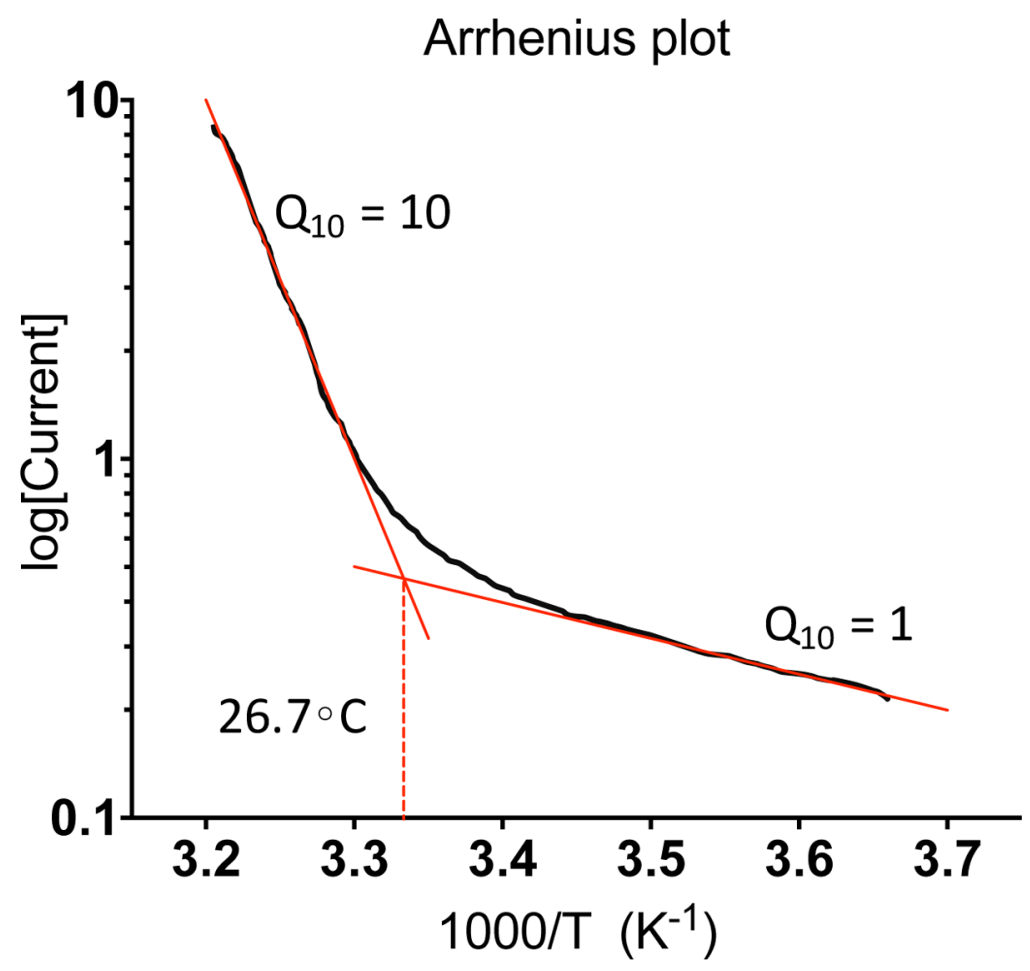

Figure 2. Arrhenius plot of a hypothetical temperature-sensitive channel

The Arrhenius plot depicts the current amplitude evoked by changes in temperature on a log scale on the $y$-axis, versus the inverse of temperature in degrees Kelvin on the $\mathrm{x}$-axis. The slope of the resulting curve reports the $\mathrm{Q}_{10}$ of the channel at different temperatures. While all proteins have some dependence on temperature, thermosensitive channels usually have a $\mathrm{Q}_{10}>5$. A typical method of quantifying the temperature threshold is to find the intersection point of two lines that lie tangent to the beginning and end of the curve (red lines). This apparent activation threshold marks the start of a detectable increase in channel activity in heterologous and native systems, which increases at a steep rate over the channel's activation range. 


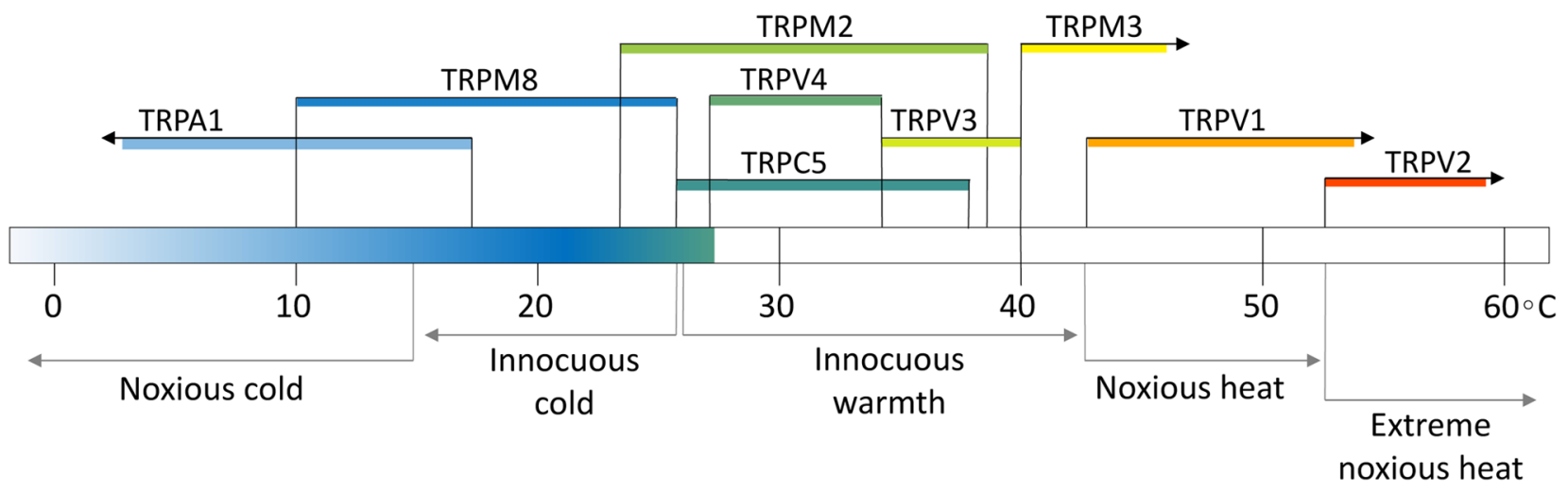

Figure 3. Temperature range of mammalian thermo-TRPs

Depicts the temperature-sensitive range of each thermo-TRP. TRPA $1\left(<17^{\circ} \mathrm{C}\right)$, TRPM8 $\left(10^{\circ} \mathrm{C}-26^{\circ} \mathrm{C}\right)$, TRPM2 $\left(23^{\circ} \mathrm{C}-28^{\circ} \mathrm{C}\right)$, TRPC5 $\left(26^{\circ} \mathrm{C}-38^{\circ} \mathrm{C}\right)$, TRPV4 $\left(27^{\circ} \mathrm{C}-34^{\circ} \mathrm{C}\right)$, TRPV3 $\left(33^{\circ} \mathrm{C}-40^{\circ} \mathrm{C}\right)$, TRPM3 $\left(>40^{\circ} \mathrm{C}\right)$, TRPV1 $\left(>42^{\circ} \mathrm{C}\right)$, TRPV2 $\left(>52^{\circ} \mathrm{C}\right)$. These overlap with psychophysical temperature ranges of noxious cold $\left(<15^{\circ} \mathrm{C}\right)$, innocuous cold $\left(10^{\circ} \mathrm{C}-\right.$ $\left.25^{\circ} \mathrm{C}\right)$, innocuous warmth $\left(25^{\circ} \mathrm{C}-42^{\circ} \mathrm{C}\right)$, noxious heat $\left(42^{\circ} \mathrm{C}-52^{\circ} \mathrm{C}\right)$, and extreme noxious heat $\left(>52^{\circ} \mathrm{C}\right)$. 

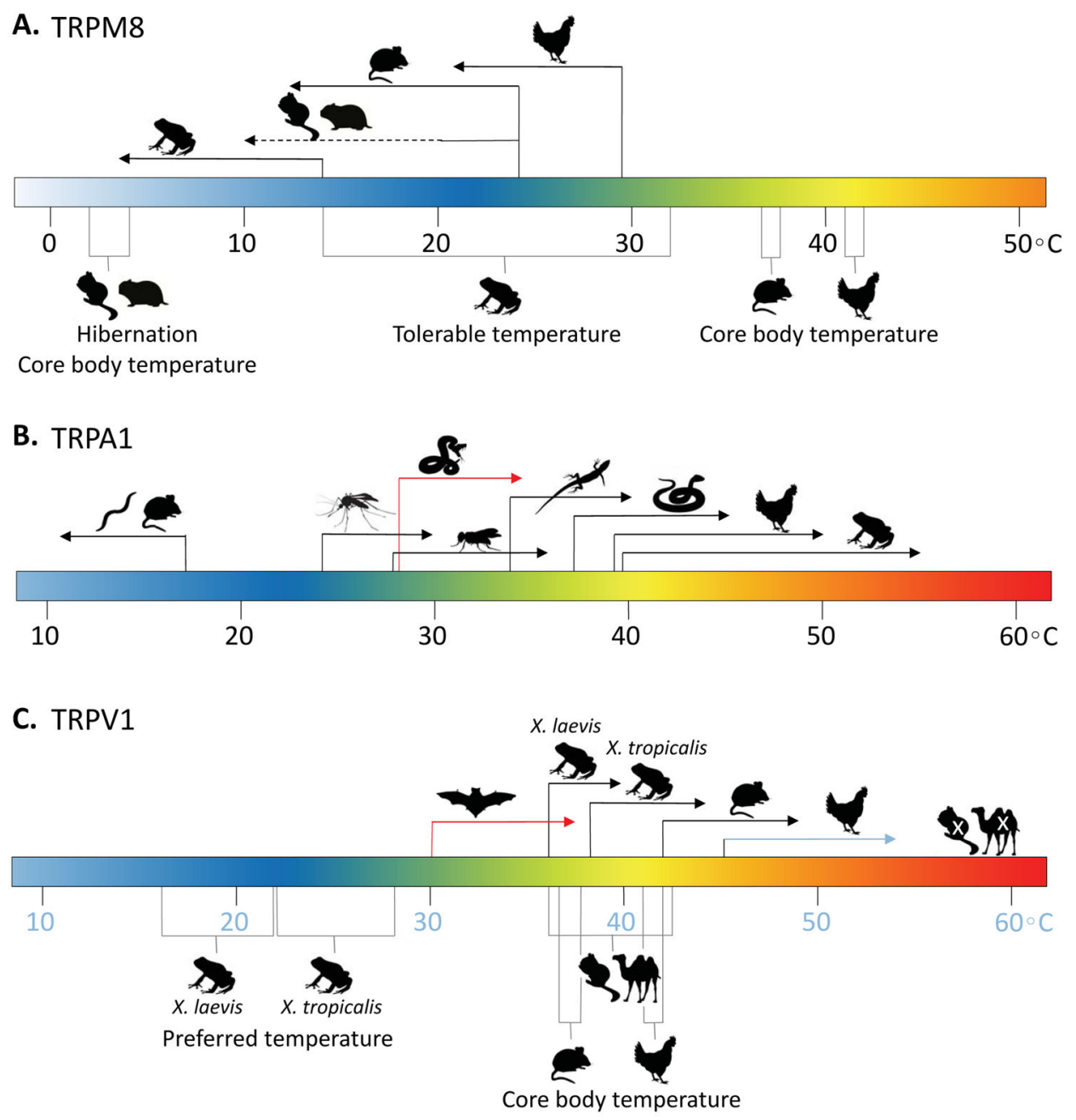

Figure 4. Species-specific temperature ranges of TRPM8, TRPA1, and TRPV1

A. Half-maximal activation temperatures of TRPM8 from chicken $\left(29.4^{\circ} \mathrm{C}\right)$, rat $\left(24^{\circ} \mathrm{C}\right)$, and frogs (13.9) correlate with the body temperature of chicken $\left(41^{\circ} \mathrm{C}-42^{\circ} \mathrm{C}\right)$ and rat $\left(\sim 37^{\circ} \mathrm{C}\right)$, and the tolerable temperature of frogs $\left(14^{\circ} \mathrm{C}-32^{\circ} \mathrm{C}\right)$. The body temperature of hibernating thirteen-lined ground squirrels and Syrian hamsters drops as low as $2^{\circ} \mathrm{C}-4^{\circ} \mathrm{C}$, which these animals may be able to tolerate due to reduced TRPM8 sensitivity in the range of $20^{\circ} \mathrm{C}$ $10^{\circ} \mathrm{C}$ (denoted by dotted line). B. TRPA1 apparent activation threshold of mouse $\left(<17^{\circ} \mathrm{C}\right)$, worm $\left(<17^{\circ} \mathrm{C}\right)$, mosquito TRPA1-B $\left(24.8^{\circ} \mathrm{C}\right)$, fruit fly TRPA1-B $\left(27.8^{\circ} \mathrm{C}\right)$, rattlesnake $\left(32.7^{\circ} \mathrm{C}\right)$, green anole $\left(33.9^{\circ} \mathrm{C}\right)$, rat snake $\left(37^{\circ} \mathrm{C}\right)$, chicken $\left(39.4^{\circ} \mathrm{C}\right)$, and frog $\left(39.7^{\circ} \mathrm{C}\right)$. Red arrow denotes specialized use of TRPA1 in snake pit organs as a radiant heat sensor. $\mathbf{C}$. TRPV1 apparent activation threshold of frog Xenopus laevis $\left(36^{\circ} \mathrm{C}\right)$, frog Xenopus tropicalis $\left(38^{\circ} \mathrm{C}\right)$, mouse $\left(>42^{\circ} \mathrm{C}\right)$, and chicken $\left(>45^{\circ} \mathrm{C}\right)$, which correlate with the preferred temperature of Xenopus laevis $\left(16^{\circ} \mathrm{C}-22^{\circ} \mathrm{C}\right)$ and Xenopus tropicalis $\left(22^{\circ} \mathrm{C}-28^{\circ} \mathrm{C}\right)$, and the body temperature of mouse $\left(\sim 37^{\circ} \mathrm{C}\right)$ and chicken $\left(41^{\circ} \mathrm{C}-42^{\circ} \mathrm{C}\right)$. Extremophiles thirteenlined ground squirrel and wild Bactrian camel tolerate a greater variation of body temperatures, and their TRPV1 homologs are not sensitive to heat. Red arrow denotes specialized use of TRPV1-S isoform as a heat sensor in pit organs of vampire bats $\left(30^{\circ} \mathrm{C}\right)$. 


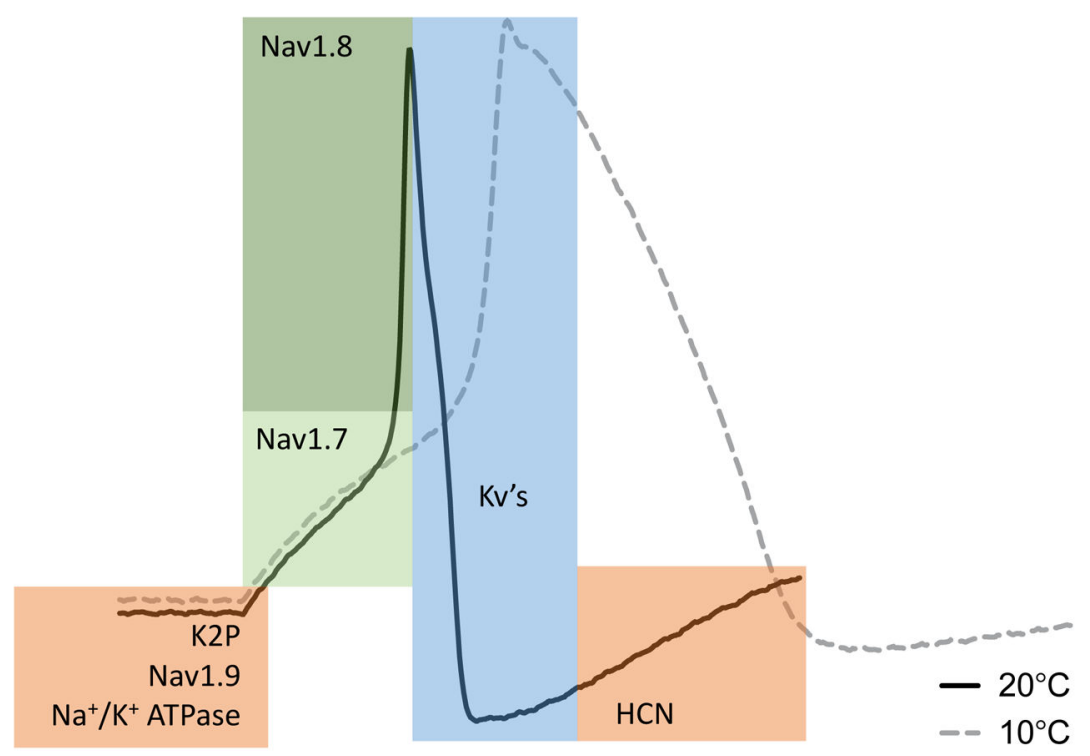

Figure 5. Main molecular components of the action potential

Shown is the typical shape of an action potential in a mouse DRG neuron at room temperature (black trace) along with major electrical conduits. Colored regions denote the areas of contribution of the indicated channels' activity to the different phases of the action potential. Nav1.7 contributes to the early depolarization and upstroke (light green). Nav1.8 contributes to the rapid upstroke (dark green). Kv's repolarize the cell in the falling phase (blue). K2P's, Nav1.9, and $\mathrm{Na}^{+} / \mathrm{K}^{+}$-ATPase regulate the resting potential of the cell, and $\mathrm{HCN}$ channels drive the return of the resting potential from the after-hyperpolarization (orange). At cold temperature, the action potential becomes much slower and broader due to temperature dependent changes of the underlying channel activity (dashed gray trace). 